Vol. 15 (2006): 351-374.

\title{
Abatement costs for agricultural nitrogen and phosphorus loads: a case study of crop farming in south-western Finland
}

\author{
Janne Helin, Marita Laukkanen and Kauko Koikkalainen \\ MTT Agrifood Research Finland, Economic Research, Luutnantintie 13, FI-00410 Helsinki, Finland, \\ e-mail: janne.helin@mtt.fi
}

\begin{abstract}
Designing efficient agri-environmental policies for agricultural nutrient load reductions calls for information on the costs of emission reduction measures. This study develops an empirical framework for estimating abatement costs for nutrient loading from agricultural land. Nitrogen abatement costs and the phosphorus load reductions associated with nitrogen abatement are derived for crop farming in south-western Finland. The model is used to evaluate the effect of the Common Agricultural Policy reform currently underway on nutrient abatement costs. Results indicate that an efficiently designed policy aimed at a $50 \%$ reduction in agricultural nitrogen load would cost $€ 48$ to $€ 35$ million, or $€ 3756$ to $€ 2752$ per farm.
\end{abstract}

Key-words: water pollution, agriculture, abatement, nitrogen, phosphorus, nutrient load

\section{Introduction}

Excessive concentrations of nutrients that regulate phytoplankton growth cause eutrophication of marine and freshwater ecosystems. The most heavily loaded marine areas in Europe show symptoms of severe eutrophication (see for example Ærtebjerg et al. 2001). The Baltic Sea ecosystem has proved particularly vulnerable to nutrient pollution. Blooms of toxic blue-green algae occur during the warm summer months, and filamentous algae cover the seabed in coastal areas. Eutrophication re- sults in significant damages through reduced value of fisheries and recreational activities (e.g. Gren et al. 1997, Söderqvist and Scharin 2000, Sandström et al. 2000, Kosenius 2004). Nutrient loading from land-based sources and the atmosphere builds up nutrient concentrations. The state of eutrophied water ecosystems can be improved by reducing nutrient loads from inland sources, which include agriculture, municipalities and industry. Agriculture has been identified as the major source of eutrophying nutrients in developed countries (see e. g. Shortle and Abler 2001). For example in the Nordic countries, municipal and industrial nutrient 
loads have been reduced significantly during the last few decades, while agricultural nutrient loads remain substantial (HELCOM 2005).

Linking nutrient load reductions with the costs of those reductions is essential for informed decision making. Abatement costs are relatively easy to assess in the case of municipal and industrial point-source pollution, whereas quantifying abatement costs for agricultural non-point pollution poses a challenge (see e.g. Russel and Shogren 1993). Nutrient removal at municipal and industrial sources requires setting up wastewater treatment facilities, after which chemical or biological nutrient removal occurs at an approximately constant cost. Agricultural abatement instead takes place through changes in agricultural practices and through adopting abatement measures that filter runoff, such as buffer strips and wetlands. Nutrient loading is affected both by agricultural management practices, such as crop choice, fertilizer use, and tillage, and by environmental factors, such as climate, soil type and field slope. Abatement costs arise from forgoing agricultural profits as a result of constraining agricultural production and altering current agricultural practices for more environmentally benign ones. Estimating agricultural abatement costs requires considerable information on nutrient loading and a detailed description of the production technology.

The costs of agricultural nutrient load reductions have been addressed in numerous studies. Mattsson and Carlsson (1983) and Johnsson (1993) analyzed the effect of nitrogen fertilization on profits from crop production in Sweden using discrete fertilization intervals. Gren et al. (1995) constructed continuous cost functions for nitrogen and phosphorus fertilization reductions in Denmark, Finland and Sweden from estimated fertilizer demand. Schou et al. (2000) applied a spatially disaggregated partial equilibrium model of Danish agriculture on nitrogen taxes and nitrate loading. Accounting for the increased knowledge on the relationship between agricultural management practices and nutrient losses, Brady (2001) modelled crop yield and nitrogen loss as continuous nonlinear functions of fertilization, with different coefficients for each cropping alternative. In addition to fertilization reduction, Brady considered catch crops and delayed tillage as abatement measures. The model was applied to estimate an abatement cost function for crop farming in Southern Sweden. Berntsen et al. (2003) evaluated the effect of four different nitrogen taxes on nitrate losses and profits on Danish pig farms, while Polman and Thijssen (2002) studied a nitrogen levy for Dutch pig farms. Johansson et al. (2004) derived phosphorus abatement cost functions for the Sand Creek basin in Minnesota using simulation data to describe the effects of 14 distinct sets of management practices on nutrient loads and profits. They considered crop rotations, fertilizer application rates and methods, and conservation tillage as abatement measures. Turpin et al. (2005) derived the direct and indirect costs for three sets of agricultural management practices using national accounting data. Petrolia and Gowda (2006) showed that nutrient management policies should be targeted at tile drained land in the Midwest of the United States.

Grass buffer strips have been shown to be an effective means to reduce nutrient loads from arable land (see e.g. Magette et al. 1987, Dillaha and Inamdar 1997, Patty et al. 1997, Uusi-Kämppä et al. 2000, Uusi-Kämppä 2005). Recent results on the effect of tillage on nutrient loads suggest that no-till also reduces erosion and particulate phosphorus losses, although the effect on total phosphorus loss is ambiguous (Puustinen 2004, unpublished results). This paper presents a framework for deriving nitrogen abatement costs that includes reductions in nitrogen fertilization rates, crop selection, buffer strips, and changes in tillage as abatement measures. Furthermore, we account for the interdependence of reductions in nitrogen and phosphorus loads. We use an approach that is similar to Brady (2001) and Johansson (2004), but extend the model to consider buffer strips and depict both nitrogen and phosphorus loads as nonlinear functions of fertilization. We apply the model to derive an abatement cost function for crop production in the Uusimaa and Varsinais-Suomi provinces in south-western Finland. The model is used to evaluate the effect of the current agricultural income support poli- 
Vol. 15 (2006): 351-374.

cies on the cost of reducing agricultural nutrient loading.

The paper is constructed as follows: the second section describes a farm-level profit maximization model that links nitrogen abatement levels and costs. In the third section, we present an empirical framework for linking agricultural management practices and nitrogen and phosphorus loading from agricultural land. The fourth section describes the application, crop farming in south-western Finland. The fifth section presents the results, and the sixth section concludes.

\section{Economic model}

The abatement cost function represents the minimum cost of achieving any desired abatement level, where the abatement level is measured as the reduction in kilograms of nutrient discharges from the unconstrained level. Thus, the abatement cost function maps the cost-minimizing choice of abatement effort necessary to achieve any abatement target. This section outlines the link between farmers' production choices and nutrient discharges. We consider the case of crop production. We adopt an integrated economic and natural science modelling approach: An economic model of farmers' decision making is combined with a biophysical model predicting the effect of farming practices on crop yield as well as nitrogen and phosphorus discharges. Similarly to Yiridoe and Weersink (1998), Brady (2001) and Johansson et al. (2004), we model abatement effort on the extensive and intensive margins. Extensive margin practices include for example crop selection and tillage method, and intensive margin practices fertilizer application rates and methods.

Formally, we consider the problem of maximizing profits from agricultural production, subject to a constraint on the allowed nitrogen discharges. The abatement cost function is obtained through varying the constraint and repeatedly solving the constrained optimization problem. By assumption, farmers use a compound fertilizer that contains nitrogen and phosphorus in fixed proportions and in the absence of constraints choose fertilizer application rates based on yield response to nitrogen application. ${ }^{1}$ The abatement measures on the extensive margin affect both nitrogen and phosphorus discharges. Consequently, nitrogen and phosphorus discharges cannot be reduced independently. Given a constraint on the allowable nitrogen discharges, phosphorus discharges are determined through the phosphorus content of the compound fertilizer and the adopted abatement measures.

Current environmental subsidies are not included in the analysis. The aim of the study is to determine the minimum cost for achieving any given load reduction target and thus to provide guidelines for designing cost-effective agri-environmental policy. Including agricultural income subsidies means that the analysis is conducted in a second-best framework, which is not unusual for studies of the agricultural sector (see e.g. Antle and Just 1991). The choice also reflects policies in the European Union (EU) in that the Common Agricultural Policy income support is decided upon at the EU level, while individual member countries are responsible for environmental policy design.

By assumption, farmers are perfectly competitive and risk-neutral. Agricultural profits are a function of the chosen farming practices. Farmers' objective is to maximize farm profits while complying with the load restriction. The choice variables are the land area allocated to each crop and tillage method, the nitrogen fertilization rate given crop and tillage method, and the area allocated to buffer strips. The constrained profit function $\pi\left(\bar{L}_{N}\right)$ gives farm profits as a function of the allowed nitrogen load $\bar{L}_{N}$ when farming practices are chosen optimally. Agricultural profits in the ab-

1 An interview study of Finnish farmers conducted as a part of the Finnish agri-environmental program evaluation indicated that Finnish cereal producers use predominantly compound fertilizers and choose the fertilizer application rate based on the nitrogen content of the fertilizer mix and yield response to nitrogen application. Phosphorus application rate follows from the phosphorus content of the compound fertilizer. (Sonja Pyykkönen, Finnish Environmental Institute, personal communication). 
sence of abatement are denoted by $\pi^{*}$. Formally, the constrained profit function $\pi\left(L_{N}\right)$ is defined by the solution to the following maximization problem:

$$
\begin{aligned}
& \max _{X_{j, k}, N_{j, k}, B_{j, k}} \pi(X, N, B)= \\
& \sum_{j=1}^{J} \sum_{k=1}^{K}\left\{\left[p_{j} f_{j, k}\left(N_{j, k}\right)-p_{N} N_{j, k}-c_{j, k}\right.\right. \\
& \left.\left.+s_{j, k}\right]\left(1-B_{j, k}\right)-c_{B, j, k} B_{j, k}\right\} X_{j, k}
\end{aligned}
$$

subject to

$$
\begin{aligned}
& \sum_{j=1}^{J} \sum_{k=1}^{K} r_{i, j, k} X_{j, k} \leq \bar{R}_{i}, \quad \forall i \\
& X_{j, k} \geq 0, \quad N_{j, k} \geq 0 \\
& N_{j, k} / P_{j, k}=\bar{F}_{j} \\
& \sum_{j=1}^{J} \sum_{k=1}^{K} B_{j, k} \leq \bar{B} \\
& \sum_{j=1}^{J} \sum_{k=1}^{K} e_{j, k}\left(N_{j, k}, B_{j, k}\right) X_{j, k} \leq \bar{L}_{N} .
\end{aligned}
$$

The notation in (1) to (6) is as follows. Subscript $j$ denotes crop and $k$ tillage method. The options for tillage method depend on the measures suitable for each particular crop. Variable $X_{j, k}$ denotes the land in hectares allocated to crop $j$ and tillage $k, N_{j, k}$ the per hectare nitrogen application rate, and $B_{j, k}$ the proportion of land left uncultivated as buffer zone. In the profit expression, $p_{j}$ denotes the average price per kilogram for crop $j$ minus yield dependent production costs, $f_{j, k}\left(N_{j, k}\right)$ crop yield as a function of nitrogen application for crop $j$ and tillage $k, s_{j, k}$ area based subsidies (excluding environmental subsidies), $c_{j, k}$ per hectare production costs, $p_{N}$ cost of applying a kilogram of nitrogen fertilizer, and $c_{B, j, k}$ cost of establishing and maintaining buffers. The per hectare production costs include labour, fuel, machinery (op- erating cost), pesticides and herbicides that are used on average to till, sow and harvest a hectare of crop $j$ using tillage $k$. In constraint (2), $r_{i, j, k}$ represents the amount of resource $i$ required to farm one hectare of crop $j$ using tillage $k$, and $\bar{R}_{i}$ is the total quantity of resource $i$ available. Resources may include for example labour, land and machinery. The constraint states that the amount of resource $i$ used in production may not exceed the total quantity of resource $i$ available. Constraint (3) ensures that land allocated to each crop and tillage as well as fertilizer application rates are nonnegative. In constraint (4), $\bar{F}_{j}$ represents the ratio of nitrogen and phosphorus in the compound fertilizer for crop $j$ : given the nitrogen fertilization rate $N_{j, k}$, the phosphorus fertilization rate $P_{j, k}$ is defined through (4). In constraint (5), $\bar{B}$ denotes the maximum land area that is suitable for buffer strips, that is, land that is adjacent to watercourses and has potential to reduce nutrient transport. Average nitrogen discharge for crop $j$ and tillage $k$ is given by $e_{j, k}\left(N_{j, k}, B_{j, k}\right)$. Finally, constraint (6) implements the constraint that nitrogen discharges may not exceed $\bar{L}_{N}$.

Solving the constrained optimization problem in (1) to (6) for all possible values of the maximum allowable nitrogen load $\bar{L}_{N}$ yields the abatement costs as a function of $\bar{L}_{N}$. The analytical solution to the problem is presented in Appendix 1. The abatement cost associated with a nitrogen load restriction $\bar{L}_{N}$ is the difference between the maximum profits from farming in the absence of load restrictions, $\pi^{*}$, and the maximum profits subject to the load constraint $\bar{L}_{N}$, denoted by $\pi\left(\bar{L}_{N}\right)$. Thus, the abatement cost function can be written as

$$
C\left(\bar{L}_{N}\right)=p^{*}-p\left(\bar{L}_{N}\right) .
$$

Given the nitrogen fertilizer application rate, crop and tillage choice, and share of buffer strips associated with each level of the nitrogen load constraint $\bar{L}_{N}$, the loads of dissolved reactive phosphorus (DRP) and particulate phosphorus (PP) are determined by the ratio of nitrogen and phosphorus in the compound fertilizer in (4), and by phosphorus loss functions which will be described in the third section below. Reducing nitro- 
Vol. 15 (2006): 351-374.

gen fertilization below the level that is optimal without load constraints will reduce agricultural profits. The effect of buffer strips, reduced tillage or no-till on profits cannot be determined a priori, as reduced yields are accompanied with cost savings that may outweigh the effect of reduced yield on profits (see e.g. Lankoski et al. 2006).

\section{Empirical specifications for crop yield and nutrient loss functions}

\section{Crop yield}

Per hectare crop yield is modelled as a function of nitrogen fertilization. Following Lehtonen (2001), the yield function for turnip rape, silage and sugarbeet is assumed to have the quadratic form

$$
f_{j, k}\left(N_{j, k}\right)=a_{j, k}+b_{j, k} N_{j, k}+c_{j, k} N_{j, k}^{2},
$$

where $f_{j, k}\left(N_{j, k}\right)$ is crop yield and $N_{j, k}$ is nitrogen application rate, both in $\mathrm{kg}$ per hectare. Lehtonen (2001) estimated the parameters in (8) for conventional tillage. The crop yield parameters for reduced tillage and no-till were obtained by adjusting the crop yield for conventional technology in Lehtonen (2001) by yield coefficients reduced tillage and no-till reported in Ekman (2000).

The crop yield function for spring wheat, barley, oats and winter wheat is assumed to follow the Mitcherlich form

$$
f_{j, k}\left(N_{j, k}\right)=m_{j, k}\left(1-l_{j, k} e^{-q_{j, k} N_{j, k}}\right)
$$

where $m_{j, k}, l_{j, k}$ and $q_{j, k}$ are parameters. The parameter values corresponding to spring wheat, barley and oats were obtained from Uusitalo and Eriksson (2004). For each tillage method $k$, the parameters for winter wheat are otherwise the same as for spring wheat, but parameter $m_{j, k}$ has been adjusted as follows: for a given fertilization rate the yield for winter wheat is 1.05 times that for spring wheat. The 5\% difference in yields corre- sponds to the average yield difference on Finnish profitability bookeeping farms in years 1995-2003 (a rotating panel of approximately 1000 farms included each year). The crop yield functions in (8) and (9) can be interpreted as average yield responses to nitrogen fertilizer application. Both the quadratic form and the Mitcherlich form are commonly used in crop response analyses (see e.g. Bock and Sikora 1990, Cerrato and Blackmer 1990, Frank et al. 1990, Bäckman et al. 1997).

\section{Nitrogen load}

Nitrogen discharges are determined by the concentration of mineral nitrogen in the soil and the quantity of water percolating through the soil. The choice of agricultural practices affects both soil nitrogen concentration and percolation. Nitrogen fertilization increases soil nitrogen concentration and has a direct impact on nitrogen loading (see e.g. Simmelsgaard 1991, Randall and Mulla 1991, Randall et al. 1997, Simmelsgaard and Djurhuus 1998). Nitrogen discharges can be controlled through the fertilizer application rate and crop choice. Nitrogen losses can also be reduced by leaving buffer strips (see e.g. Uusi-Kämppä and Yläranta 1992, Uusi-Kämppä and Yläranta 1996, Uusi-Kämppä and Kilpinen 2000). Tillage has been shown to have only a minor effect on nitrogen loss for a given fertilization rate (see Randall and Mulla 2001, Puustinen 2004 unpublished results).

We next describe the effect of fertilizer application rate and crop choice on average nitrogen discharge per hectare. Following Simmelsgaard (1991) and Simmelsgaard and Djurhus (1998), we calculate per hectare nitrogen loss through

$$
e_{j, k}\left(N_{j, k}\right)=\phi_{j, k} \exp \left[0.71\left(N_{j, k} / \bar{N}_{j, k}-1\right)\right] .
$$

Parameter $\phi_{j, k}$ captures the average nitrogen loss for crop $j$ and tillage $k$ in kilograms per hectare and is specific to land characteristics (slope, soil type etc.) and drainage system. ${ }^{2}$ Term

2 Crop selection, tillage and fertilization rate are choice variables in our model while land characteristics and 
$\exp \left[0.71\left(N_{j, k} / \bar{N}_{j, k}-1\right)\right]$ measures the intensity of the actual fertilization rate $N_{j, k}$ relative to a reference rate $\bar{N}_{j, k}$, with $0.5 \leq N_{j, k} / \bar{N}_{j, k} \leq 1.5$.

Buffer strips reduce nutrient losses via two channels: nutrient uptake by buffer strips and reduction in the amount of fertilizer applied. Nutrient uptake only affects surface losses. Denoting the proportions of nitrogen losses via surface runoff and drainage water by $n_{s}$ and $n_{d}$, per hectare nitrogen loss in the presence of buffer strips can be written as

$$
\begin{aligned}
& e_{j, k}\left(N_{j, k}, B_{j, k}\right)= \\
& {\left[n_{s}\left(1-B_{j, k}^{0.2}\right)+n_{d}\right] \phi_{j, k} \exp \left\{0 . 7 1 \left[\left(1-B_{j, k}\right) N_{j, k} /\right.\right.} \\
& \left.\left.\bar{N}_{j k}-1\right]\right\}
\end{aligned}
$$

The term $n_{s}\left(1-B_{j, k}^{0.2}\right)$ gives nitrogen uptake by buffer strips, and $B_{j, k}$ denotes the share of land allocated to buffer strips. The second term on the right hand side of (11) accounts for the reduction in fertilizer applied. The parameterization in (11) follows Lankoski et al. (2006), who calibrated the model to data from Finnish experimental studies on grass buffer strips (Uusi-Kämppä and Yläranta 1992, Uusi-Kämppä and Yläranta 1996, UusiKämppä and Kilpinen 2000).

Given the per hectare nitrogen losses in (11), the total nitrogen loss, denoted by $L_{N}$, is

$$
L_{N}=\sum_{j=1}^{J} \sum_{k=1}^{K} e_{j, k}\left(N_{j, k}, B_{j, k}\right) X_{j, k} .
$$

\section{Phosphorus load}

Phosphorus is transported from agricultural land to surface water in two forms: (i) dissolved reactive

drainage system are assumed to be given. Petrolia and Gowda (2006) considered plugging artificial drainage as an abatement policy but found reducing fertilization rates and retiring land to be more profitable measures. Simmelsgaard and Djurhus studied the effect of fertilization intensity on nitrogen loss from tile drained sandy-loam soil, while the predominant soil type in south-western Finland is clay. Section 4 reports how the $\phi_{j, k}$ have been adjusted to describe conditions in the study region. phosphorus (DRP) and (ii) particulate phosphorus (PP). Discharges of both DRP and PP are affected by the fertilizer application rate, crop choice, and tillage method. No-till and reduced tillage are emerging as effective ways to reduce erosion and total phosphorus loading (see e.g. Soileau et al. 1994, Stonehouse 1997, Puustinen 2004 unpublished results, Puustinen et al. 2005). Buffer strips have also been shown to reduce phosphorus loading (Uusi-Kämppä and Yläranta 1992, UusiKämppä and Yläranta 1996, Uusi-Kämppä and Kilpinen 2000). Phosphorus loss is modelled below following Lankoski et al. (2006), who used results from Finnish studies on grass buffer strips (Uusi-Kämppä and Kilpinen 2000) and DRP losses (Uusitalo and Jansson 2002), and long-term fertilizer trials (Saarela et al. 1995, Saarela et al. 2003) to construct phosphorus loss functions.

The losses of dissolved reactive phosphorus and particulate phosphorus in kilograms per hectare are given by

$$
\begin{aligned}
& z_{D R P, j, k}\left(P_{j, k}, B_{j, k}\right)=\left[\left(1-B_{j, k}^{1.3}\right) d r p_{s}+d r p_{d}\right] . \\
& \sigma_{j, k}\left[2\left(\theta+0.01\left(1-B_{j, k}\right) P_{j, k}\right)-1.5\right] \cdot 10^{-4}, \\
& z_{P P, j, k}\left(P_{j, k}, B_{j, k}\right)=\left[\left(1-B_{j, k}^{0.3}\right) p p_{s}+p p_{d}\right] \Delta_{j, k} . \\
& \left\{250 \ln \left[\theta+0.01\left(1-B_{j, k}\right) P_{j, k}\right]-150\right\} \cdot 10^{-6} .
\end{aligned}
$$

The terms $\left(1-B_{j, k}^{1.3}\right)$ and $\left(1-B_{j, k}^{0.3}\right)$ capture phosphorus uptake by buffer strips. The proportions of DRP loss via surface flow and drainage water are denoted by $d r p_{s}$ and $d r p_{d}$, and the proportions of PP loss via surface flow and drainage water by $p p_{s}$ and $p p_{d}$. Parameter $\sigma_{j, k}(\mathrm{~mm})$ describes the impact of crop choice $j$ and tillage $k$ on DRP loss, summarizing the effects on total runoff and its DRP content; $\theta\left(\mathrm{mg} \mathrm{l}^{-1}\right)$ is the soil phosphorus status $^{3}, P_{j, k}$ the phosphorus fertilizer application rate $\left(\mathrm{kg} \mathrm{ha}^{-1}\right)$; and $\Delta_{j, k}\left(\mathrm{~kg} \mathrm{ha}^{-1}\right)$ summarizes the impact of crop $j$ and tillage $k$ on erosion and the PP con-

\footnotetext{
3 The parameterization obtains when soil phosphorus status $\theta$ is between 9 and $13 \mathrm{mg} \mathrm{l}^{-1}$.
} 
Vol. 15 (2006): 351-374.

tent of eroded soil. Fertilizer is not applied on the buffer strip area $B_{j, k}$.

The total losses of dissolved reactive phosphorus and particulate phosphorus are

$$
\begin{aligned}
& L_{D R P}=\sum_{j=1}^{J} \sum_{k=1}^{K} z_{D R P, j, k}\left(P_{j, k}, B_{j, k}\right) X_{j, k} \\
& L_{P P}=\sum_{j=1}^{J} \sum_{k=1}^{K} z_{P P, j, k}\left(P_{j, k}, B_{j, k}\right) X_{j, k} .
\end{aligned}
$$

\section{Agriculture in Southern Finland}

We utilize data from the Uusimaa and VarsinaisSuomi provinces in Southern Finland to estimate the abatement cost function. Agricultural loading from southern Finland constitutes the largest anthropogenic nutrient source in the Finnish coastal waters of the Gulf of Finland, which is the most eutrophied sub-basin of the Baltic Sea. The shallow coastal waters are particularly prone to eutrophication, and toxic algae blooms frequently occur during the warm summer months. The Helsinki Commission has called for more effort to reduce the nutrient loads to the Baltic Sea, especially from agriculture (HELCOM). In Finland, agricultural nutrient abatement is the single most important investment under the Water Protection Target Programme (HELCOM 2003). The main objective of Finnish Agro-Environmental Subsidy Programme is the reduction of nutrient loads to waterways (Turtola and Lemola 2004). Besides the Baltic Sea, these priorities relate to the majority of Finnish lakes, which are shallow and hence vulnerable to nutrient pollution. Despite past efforts to reduce nutrient loads from arable land, the nutrient levels have not been decreasing (Ekholm et al. 2004, Räike and Granlund 2004, Granlund et al. 2005).

Figure 1 depicts the study area. Economic data pertain to the regional economic and employment development centers in the Uusimaa and VarsinaisSuomi provinces, while the ecological data come from the catchment area that approximately corresponds to the two provinces. The area of culti- vated agricultural land in the region was 481500 hectares in 2003, which represents approximately $20 \%$ of cultivated land in Finland. The average farm size in 2003 was 38 ha. Agriculture in the region is predominantly crop farming - only $19 \%$ of the 12632 farms in operation in 2003 were engaged in animal production. The crops that took up the highest percentage of cultivated land in 2003 were barley (24\%), spring wheat (22\%), and oats $(13 \%)$. Other commonly grown crops were turnip rape $(6 \%)$, winter wheat $(5 \%)$, silage $(5 \%)$, and sugar beet $(3 \%)$. (Yearbook of farm statistics 2004). Average yields for the crops are shown in Table 1. We included these seven crops and green fallow as land use choices in our model. Both malting barley and feed barley are grown in the study region. The share of malting barley was $55 \%$ in 2003 (TIKE 2004). Unfortunately distinct yield functions are not available for feed and malting barley and thus they cannot be considered as distinct crops in our model. As we are concerned with crop farms, we proceed from the assumption that the representative farm plants malting barley which has a higher price. The climate is seasonal and the thermal growing season lasts for 160-190 days. The predominant soil type is clay (vertic and dystric cambisols and haplic podzols) (Lilja et al. 2006). In 2003, conventional tillage (i.e. moldboard plowing in the autumn) was predominant. About 74 and $77 \%$ of the total cultivated land in the region is drained with subsurface drains (Finnish Field Drainage Center 2002). The average field slope (measured 30 meters from river/drain bank) in Finland is $188 \mathrm{~cm} / 100 \mathrm{~m}$ (Puustinen et al. 1994).

We analyze the farming decisions at the level of a single representative farm, and scale up the farm to represent the entire region. We consider farming decisions where the time horizon is one year. The area of land allocated to different crops is restricted by farm size, 38 hectares. ${ }^{4}$ By assump-

\footnotetext{
4 We proceed from the assumption that the amount of total agricultural land in the region is fixed. As the CAP subsidy system does not grant subsidy rights to fields cleared after 2003, it is unlikely that the agricultural land will be expanded notably. Retiring agricultural land through conversion into forest is a long term decision that
} 


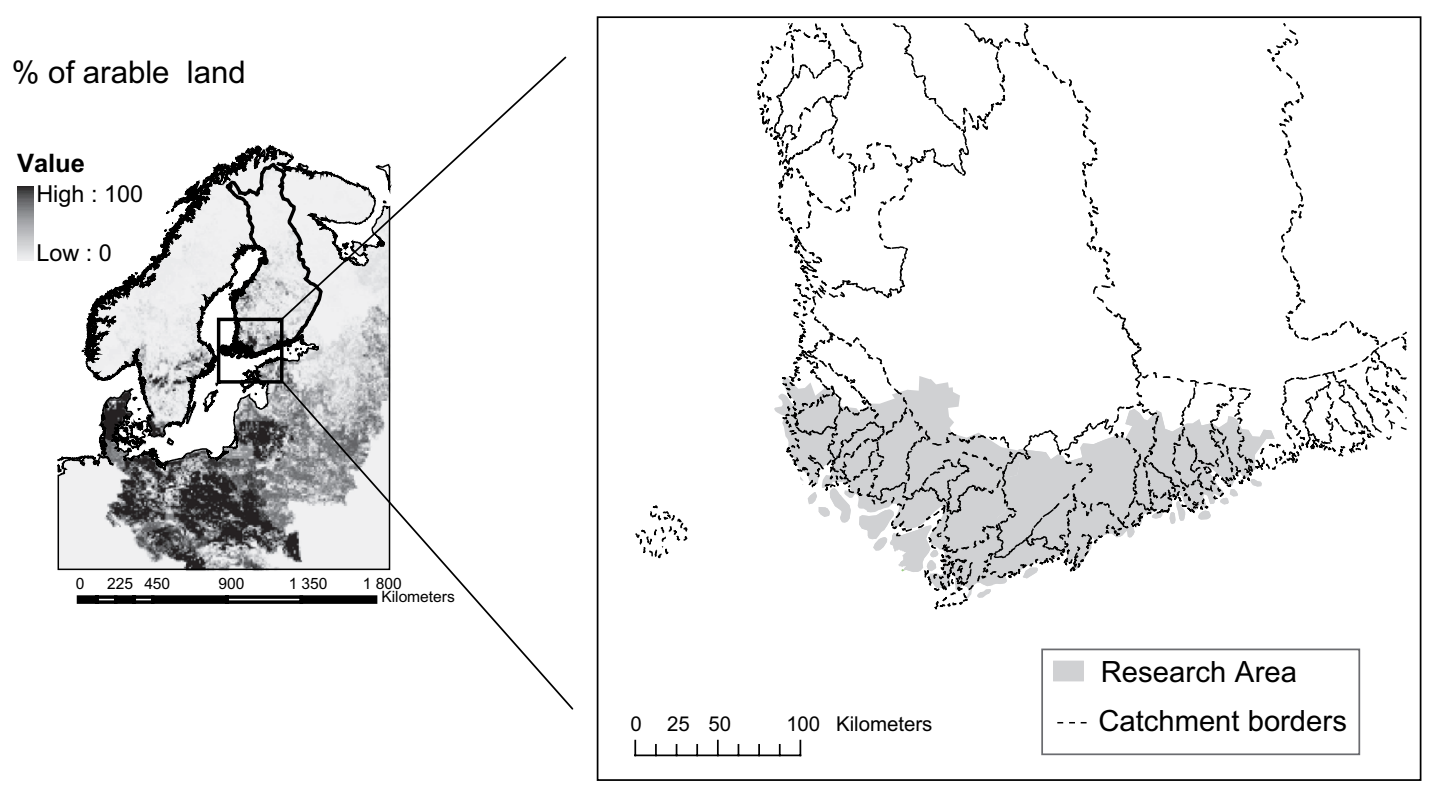

Fig. 1. Baltic Sea drainage basin and the research area.

tion, labor is not constrained, and machinery can be rented, so that all technologies (conventional, reduced tillage, and no-till) are available. Nutrient discharges can be reduced through changes in crop selection, reduced tillage and no-till, through establishing buffer strips, and through reducing fertilization. We next describe how the parameters describing the representative farm were obtained.

The agricultural commodity prices and fertilizer prices are the annual averages for 2003 (Table 1). As part of malting barley yield generally does not meet the quality requirement for malting and is sold as fodder, we use a weighted average of feed and malting barley prices. The weight of malting barley was $80 \%$, which corresponds to the yield share meeting the quality requirements for malting barley in 2003 (TIKE 2004). The yield parameters

under the current CAP policy entails losing subsidy rights. Our model is not able to account for such irreversible investments. The assumption that total area of agricultural land is fixed implies that the size of the representative farm is fixed. In reality a single farm can rent land and is not necessarily bound by such constraint. are shown in Tables 2 and 3 and the costs in Table 4. The per hectare costs include fuel and labor costs, machinery, plant protectants, and harvest, while grain drying costs are yield dependent. Fixed costs of capital are not included in the analysis. The model calculations are based on the use of compound fertilizers that contain nitrogen and phosphorus in a fixed ratio. We considered fertilizer mixes that are predominant in the production of each crop type in Finland. The nutrient ratios are given in Table 5 .

Buffer strips that are at the maximum 3 meters wide are eligible for the EU Common Agricultural Policy (CAP) area subsidies. The buffer strip potential was estimated based on GIS data of field edges next to water ways and main ditches obtained from The Information Centre of the Ministry of Agriculture and Forestry. The upper limit of buffer strip area was $0.58 \%$ or 0.22 ha for a 38 ha farm. Further buffer capacity can be obtained by adoption of wider buffer zones, which are not entitled to CAP subsidies but do receive EU Less Favored Area (LFA) payments. The regional environmental administration has estimated that $1-3 \%$ of 
Vol. 15 (2006): 351-374.

Table 1. Commodity and fertilizer prices, EUR kg-1 a and average yield in the region, $\mathrm{kg} \mathrm{ha}^{-1}$ a.

\begin{tabular}{lcr}
\hline Commodity & Prices & Yield \\
\hline Spring wheat & 0.127 & 3536 \\
Barley & 0.130 & 3488 \\
Oats & 0.099 & 3442 \\
Winter wheat & 0.127 & 3365 \\
Turnip rape & 0.260 & 1246 \\
Silage & 0.034 & 14449 \\
Sugar beet & 0.054 & 31701 \\
Fertilizers ${ }^{\text {b }}$ & & \\
$\quad$ Spring cereal composite fertilizer & 1.20 & \\
Winter cereal composite fertilizer & 1.10 & \\
Root vegetable composite fertilizer & 1.56 & \\
\hline
\end{tabular}

a Yearbook of farm statistics 2004.

b The fertilizer price was computed as the price of one $\mathrm{kg}$ of nitrogen assuming that a fertilizer mix appropriate for each crop type is applied. Spring cereal mix is applied to spring wheat, barley, oats, and turnip rape. Winter cereal mix is applied to winter wheat, and root vegetable mix to sugar beet. the arable land area would benefit from such buffer zones (Penttilä 2003). Accordingly, the upper limit for buffer zones was set at $3 \%$, which corresponds to 1.14 ha for a 38 ha farm.

Parameters $\varphi_{j, k}, \sigma_{j, k}$ and $\Delta_{j, k}$ in the functions describing the losses of nitrogen, dissolved reactive phosphorus and particulate phosphorus (equations 10 to 16) were calibrated as follows: given the predominant agricultural practices in 2003 (land allocation, fertilizer application, buffers, and tillage), parameters $\varphi_{j, k}, \sigma_{j, k}$ and $\Delta_{j, k}$ were set at values for which the nutrient losses predicted by equations (12), (15) and (16) equaled the observed loads in 2003, whereby the relative nutrient losses produced by the different crops were held fixed. For nitrogen, the relative loads for the different crops were based on field experiments in South-Western Finland (Tapio Salo, MTT Agrifood Research Finland, personal communication). For phosphorus, the relative loads were based on simulations from the IceCream model (Tattari et al. 2001). Land al-

Table 2. Crop yield parameters for Mitcherlich form ${ }^{\mathrm{a}}$.

\begin{tabular}{|c|c|c|c|c|c|c|c|c|c|}
\hline \multirow[t]{2}{*}{ Crop } & \multicolumn{3}{|c|}{ Conventional tillage } & \multicolumn{3}{|c|}{ Chisel plough } & \multicolumn{3}{|c|}{ No-till } \\
\hline & $\mathrm{m}$ & $\mathrm{k}$ & $\mathrm{b}$ & $\mathrm{m}$ & $\mathrm{k}$ & $\mathrm{b}$ & $\mathrm{m}$ & $\mathrm{k}$ & $\mathrm{b}$ \\
\hline Spring wheat & 4871.0 & 0.7623 & 0.0104 & 4747.2 & 0.7623 & 0.0104 & 3937.3 & 0.7623 & 0.0104 \\
\hline Barley & 5309.6 & 0.8280 & 0.0168 & 5421.2 & 0.8280 & 0.0168 & 5105.1 & 0.8280 & 0.0168 \\
\hline Oats & 5659.1 & 0.7075 & 0.0197 & 5677.0 & 0.7075 & 0.0197 & 5368.4 & 0.7075 & 0.0197 \\
\hline Winter wheat & 5114.55 & 0.7623 & 0.0104 & 4984.56 & 0.7623 & 0.0104 & 4134.17 & 0.7623 & 0.0104 \\
\hline
\end{tabular}

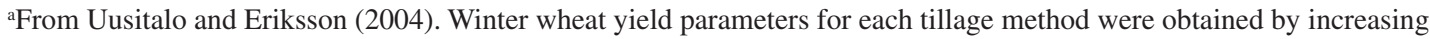
parameter $m$ for spring wheat by $5 \%$, which corresponds to the average yield difference between spring wheat and winter wheat on Finnish farm accounting data network farms in years 1995-2003.

Table 3. Crop yield parameters quadratic forma ${ }^{\mathrm{a}}$

\begin{tabular}{|c|c|c|c|c|c|c|c|c|c|}
\hline \multirow[t]{2}{*}{ Crop } & \multicolumn{3}{|c|}{ Conventional tillage } & \multicolumn{3}{|c|}{ Chisel plough } & \multicolumn{3}{|c|}{ No-till } \\
\hline & a & $b$ & $\mathrm{c}$ & a & $\mathrm{b}$ & $\mathrm{c}$ & a & $\mathrm{b}$ & $\mathrm{c}$ \\
\hline Turnip rape & 1096.1 & 9.82 & -0.0354 & 1052.26 & 9.82 & -0.0354 & 986.49 & 9.82 & -0.0354 \\
\hline Silage & 1182.9 & 24.24 & -0.0394 & \multirow{2}{*}{\multicolumn{3}{|c|}{ Not applicable }} & & & \\
\hline Sugarbeet & 23630.0 & 53.21 & -0.083 & & & & & & \\
\hline
\end{tabular}

${ }^{a}$ For conventional technology, the parameters are from Lehtonen (2001). The parameters for chisel plough and notill have been obtained by adjusting the crop yield parameters in Lehtonen (2001) by yield coefficients for chisel plough and no-till reported in Ekman (2000). 
Helin, J. et al. Abatement costs for agricultural nutrient load in SW Finland

Table 4. Crop production fixed costs, EUR ha-1 a

\begin{tabular}{|c|c|c|c|c|c|c|}
\hline \multirow[t]{2}{*}{ Crop } & \multicolumn{2}{|c|}{ Conventional tillage } & \multicolumn{2}{|c|}{ Chisel plough } & \multicolumn{2}{|c|}{ No-till } \\
\hline & Capital cost & Operation cost & Capital cost & Operation cost & Capital cost & Operation cost \\
\hline Spring wheat & 323 & 113 & 320 & 113 & 314 & 109 \\
\hline Winter wheat & 323 & 113 & 320 & 113 & 314 & 109 \\
\hline Barley & 323 & 113 & 320 & 113 & 314 & 109 \\
\hline Oats & 323 & 113 & 320 & 113 & 314 & 109 \\
\hline Turnip rape & 323 & 113 & 320 & 113 & 314 & 109 \\
\hline Silage & 235 & 148 & n.a. & n.a. & n.a. & n.a. \\
\hline Sugar beet & 384 & 327 & n.a. & n.a. & n.a. & n.a. \\
\hline Green fallow & 109 & 68 & 108 & 68 & 91 & 40 \\
\hline Buffer zone & 109 & 133 & 108 & 133 & 91 & 105 \\
\hline \multicolumn{7}{|c|}{ Grain drying costs, EUR kg-1 b } \\
\hline $\begin{array}{l}\text { Spring wheat, winter } \\
\text { wheat, barley, oats }\end{array}$ & \multicolumn{6}{|c|}{0.01 for all tillage practices } \\
\hline
\end{tabular}

${ }^{a}$ Calculated for the representative farm (38 ha) using Pentti (2003) and Enroth (2004). The buffer zone costs consist of the fixed costs of fallow, and a cost of $65 \mathrm{EUR} \mathrm{ha}^{-1} \mathrm{a}^{-1}$ for removing plant residue at the end of the growing season.

${ }^{\mathrm{b}}$ From http://www.maaseutukeskus.fi/julkaisut/s_julkaisut.htm

Table 5. Ratio of phosphorus and nitrogen in the fertilizer mix applicable to each crop ${ }^{\mathrm{a}}$.

\begin{tabular}{lc}
\hline Crop & Ratio \\
\hline Spring wheat & 0.15 \\
Barley & 0.15 \\
Oats & 0.15 \\
Winter wheat & 0.12 \\
Turnip rape & 0.15 \\
Silage & 0.14 \\
Sugar beet & 0.11 \\
Green fallow & n. a. \\
\hline
\end{tabular}

${ }^{\text {a }}$ From http://www.maaseutukeskus.fi/julkaisut/s_ julkaisut.htm.

location was set equal to the one observed in 2003; tillage was conventional; and fertilizer use was set equal to levels recommended by the Finnish environmental subsidy program in 2003 (Table 7) Soil phosphorus status $\theta$ was fixed at $10.6 \mathrm{mg} \mathrm{l}^{-1}$,

5 Farmers participating in the Finnish environmental subsidy program are required not to exceed the recommended nitrogen fertilization rates reported in Table 7. which is the average for Finnish Farm Accountancy Data Network farms situated in southern and south-western Finland (Myyrä et al. 2003). The proportions of nutrient loss incurring through surface flow were set at $0.5,0.7$ and 0.7 for nitrogen, dissolved reactive phosphorus, and particulate phosphorus, respectively, which correspond to average values in Turtola and Paajanen 1995. The calibrated parameters are presented in Table $6 .^{6}$

\footnotetext{
About 98\% farms in Finland participated in the program in 2003 (Ministry of Agriculture and Forestry 2004).

6 An approach more in line with the economic parameterization of the model would have been to use average parameter values obtained in field experiments in Finland and average soil characteristics in the region. Unfortunately this approach provided a poor approximation in our study: predicted losses for the study region as a whole were only about $40-50 \%$ of the observed nutrient loads in 2003. The discrepancy is probably due to a large part of the actual nutrient losses originating from a small proportion of agricultural land that has a very high nutrient loss potential relative to the average nutrient loss potential. As our representative farm model and the available data do not allow accounting for such high risk areas, calibrating the parameter values was deemed to be an approach yield-
} 
Vol. 15 (2006): 351-374.

Table 6. Technology- and crop specific impacts on nutrient losses ${ }^{\mathrm{a}}$.

\begin{tabular}{|c|c|c|c|c|c|c|c|c|c|}
\hline \multirow[t]{2}{*}{ Crop } & \multicolumn{3}{|c|}{ Conventional tillage } & \multicolumn{3}{|c|}{ Chisel plough } & \multicolumn{3}{|c|}{ No-till } \\
\hline & $\varphi\left(\mathrm{kg} \mathrm{ha}^{-1}\right)$ & $\sigma(\mathrm{mm})$ & $\Delta\left(\mathrm{kg} \mathrm{ha}^{-1}\right)$ & $\varphi\left(\mathrm{kg} \mathrm{ha}^{-1}\right)$ & $\sigma(\mathrm{mm})$ & $\Delta\left(\mathrm{kg} \mathrm{ha}^{-1}\right)$ & $\varphi\left(\mathrm{kg} \mathrm{ha}^{-1}\right)$ & $\sigma(\mathrm{mm})$ & $\Delta\left(\mathrm{kg} \mathrm{ha}^{-1}\right)$ \\
\hline Spring wheat & 24 & 326 & 235 & 24 & 357 & 101 & 24 & 349 & 140 \\
\hline Winter wheat & 21 & 355 & 226 & 21 & 355 & 221 & 21 & 363 & 223 \\
\hline Barley & 21 & 316 & 220 & 20 & 342 & 86 & 21 & 322 & 125 \\
\hline Oats & 12 & 323 & 224 & 12 & 347 & 90 & 13 & 347 & 129 \\
\hline Turnip rape & 26 & 329 & 244 & 24 & 357 & 110 & 25 & 340 & 149 \\
\hline Silage & 13 & 630 & 58 & n.a. & n.a. & n.a. & n.a. & n.a. & n.a. \\
\hline Sugar beet & 19 & 362 & 294 & n.a. & n.a. & n.a. & n.a. & n.a. & n.a. \\
\hline Green fallow & 12 & 197 & 9 & 12 & 197 & 9 & 12 & 197 & 9 \\
\hline
\end{tabular}

${ }^{a}$ Calibrated so that the nitrogen and phosphorus loads predicted by the loss functions (11) to (13) correspond to observed loads when land allocation is as in 2003, and fertilizer use conforms to current environmental regulations.

Table 7. Recommended nitrogen fertilization dose.

\begin{tabular}{lc}
\hline Crop & Fertilization dose, $\mathrm{kg} \mathrm{ha}^{-1 \mathrm{a}}$ \\
\hline Spring wheat & 100 \\
Barley & 90 \\
Oats & 90 \\
Winter wheat & 120 \\
Turnip rape & 100 \\
Silage & 180 \\
Sugar beet & 120 \\
Green fallow & 0 \\
\hline
\end{tabular}

${ }^{a}$ The amounts of nitrogen recommended by the Finnish Agri-Environmental support program. Source: Valtioneuvoston asetus luonnonhaittakorvauksista ja maatalouden ympäristötuesta 29.6.2000/644. Available on the Internet: http://www.finlex.fi/fi/laki/smur/2000/20000644.

Agricultural policy in terms of area based income subsidies is taken as given. The EU Common Agricultural Policy provides farmers with direct subsidy payments for crops planted. A reform of the system is currently underway. According to the European Commission, the CAP reform agreed upon in June 2003 is geared towards consumers and taxpayers and linked to the respect of environ-

ing more accurate predictions for the study region as a whole. mental, food safety and animal welfare standard (European Commission 2005). The reform levels the CAP hectare subsidy for different crop types and fallow. In Finland, the reform comes into force in 2006. In order to examine how the reform affects the cost of agricultural nutrient abatement, we considered two subsidy regimes: the one that prevailed in 2003 and the subsidy regime in place after the reform. In what follows we refer to the two subsidy regimes as BASE 2003 and CAP 2006. In order to eliminate the effects of year-toyear fluctuation, in both scenarios the commodity prices and costs were held at their 2003 levels. The level of subsidies for 2006 is based on the estimates of the Ministry of Agriculture and Forestry (2006). The subsidies under the two CAP systems are displayed in Tables 8 and 9. Finally, Table 10 summarizes the EU regulatory constraints on production.

To solve the constrained optimization problem in (1) to (6) the model was translated into the General Algebraic Modelling System (GAMS) language (Brooke and Kendrick 1998). The resulting nonlinear mathematical program was solved using the CONOPT3 optimization algorithm (see Drud 2004). We proceeded by first computing the unconstrained maximum profits $\pi^{*}$ and the associated nitrogen load $L_{N}^{*}$. Using the unconstrained solution as the baseline, the model was then solved for a series of tightening abatement targets ranging 
Helin, J. et al. Abatement costs for agricultural nutrient load in SW Finland

Table 8. Subsidies in 2003, EUR ha ${ }^{-1}$ a

\begin{tabular}{|c|c|c|c|c|c|c|c|c|}
\hline \multirow[t]{2}{*}{ Crop } & \multicolumn{2}{|c|}{ CAP payments } & \multicolumn{2}{|c|}{ LFA support } & \multicolumn{2}{|c|}{ National support } & \multicolumn{2}{|c|}{ Total subsidies } \\
\hline & A & B & A & B & A & B & A & B \\
\hline Spring wheat & 279 & 230 & 150 & 200 & 105 & 105 & 534 & 535 \\
\hline Winter wheat & 279 & 230 & 150 & 200 & 105 & 105 & 534 & 535 \\
\hline Barley ${ }^{\mathrm{b}}$ & 279 & 230 & 150 & 200 & 84 & 84 & 513 & 514 \\
\hline Oats & 279 & 230 & 150 & 200 & 9 & 9 & 438 & 488 \\
\hline Silage & 214 & 176 & 150 & 200 & 0 & 0 & 364 & 376 \\
\hline Turnip rape & 279 & 203 & 150 & 200 & 143 & 143 & 572 & 546 \\
\hline Sugar beet & 0 & 0 & 150 & 200 & 202 & 202 & 352 & 402 \\
\hline Fallow & 214 & 176 & 150 & 200 & 0 & 0 & 364 & 414 \\
\hline Buffer, width 3 to $15 \mathrm{~m}$ & 0 & 0 & 150 & 200 & 0 & 0 & 150 & 200 \\
\hline Buffer, width below $3 \mathrm{~m}$ & \multicolumn{8}{|c|}{ Same as main crop } \\
\hline
\end{tabular}

a Niemi and Ahlstedt (2003).

b The national support for malting barley. The national support for feed barley was 9 EUR ha-1.

Table 9. Subsidies in 2006, EUR ha-1.

\begin{tabular}{|c|c|c|c|c|c|c|c|c|}
\hline \multirow[t]{2}{*}{ Crop } & \multicolumn{2}{|c|}{ CAP payments ${ }^{\mathrm{a}}$} & \multicolumn{2}{|c|}{ LFA support ${ }^{\mathrm{b}}$} & \multicolumn{2}{|c|}{ National support $^{\mathrm{c}}$} & \multicolumn{2}{|c|}{ Total subsidies } \\
\hline & A & B & A & B & A & B & A & $\mathrm{B}$ \\
\hline Spring wheat & 290 & 240 & 170 & 220 & 105 & 105 & 565 & 565 \\
\hline Winter wheat & 290 & 240 & 170 & 220 & 105 & 105 & 565 & 565 \\
\hline Barley & 290 & 240 & 170 & 220 & 84 & 84 & 544 & 544 \\
\hline Oats & 240 & 190 & 170 & 220 & 6 & 6 & 416 & 416 \\
\hline Silage & 240 & 190 & 170 & 220 & 0 & 0 & 410 & 410 \\
\hline Turnip rape & 290 & 240 & 170 & 220 & 129 & 129 & 589 & 589 \\
\hline Sugar beet & 240 & 190 & 170 & 220 & 129 & 129 & 539 & 539 \\
\hline Fallow & 240 & 190 & 170 & 220 & 0 & 0 & 410 & 410 \\
\hline Buffer, width 3 to $15 \mathrm{~m}$ & 0 & 0 & 170 & 220 & 0 & 0 & 170 & 220 \\
\hline Buffer, width below $3 \mathrm{~m}$ & \multicolumn{8}{|c|}{ Same as main crop } \\
\hline
\end{tabular}

${ }^{a}$ Estimate for single farm payment combined with the crop specific production subsidy (Ministry of Agriculture and Forestry 2006).

${ }^{\mathrm{b}}$ Least favoured area (LFA) subsidy and its national increment (Ministry of Agriculture and Forestry 2006).

${ }^{\mathrm{c}}$ National support (Ministry of Agriculture and Forestry 2006).

from 0 to $60 \%$ of the unconstrained nitrogen load $L_{N}^{*}$. Each one of the $h=1, \ldots, 30$ iterations reduced the allowed load by a further $2 \%$. The allowable nitrogen load $\bar{L}_{N, h}$ associated with abatement target $A_{N, h}$ is $\bar{L}_{N, h}=L_{N}^{*}-A_{N, h}$ and the abatement cost $c_{k}=\pi^{*}-\pi\left(\bar{L}_{N, h}\right)$. A quadratic abatement cost function

$$
C\left(A_{N}\right)=\beta A_{N}^{2}
$$

was fitted to the resulting abatement target and cost pairs. Appending an additive error term to equation (17) gives rise to the linear regression model $c_{h}=\beta A_{N, h}^{2}+\varepsilon_{h}$. We interpret the error terms $\varepsilon_{h}$ as deviations of the abatement cost generated 
Vol. 15 (2006): 351-374.

Table 10. Resource and EU regulatory constraints.

\begin{tabular}{lc}
\hline Resource & EU regulatory constraint \\
\hline $\begin{array}{l}\text { Total land on representative } \\
\text { farm }\end{array}$ & 38 ha \\
$\begin{array}{l}\text { Maximum turnip rape area } \\
\text { (agronomic constraint) }\end{array}$ & 9.5 ha \\
$\begin{array}{l}\text { Maximum fallow ( } E U \\
\text { regulatory constraint) }\end{array}$ & 19 ha \\
$\begin{array}{l}\text { Minimum fallow (EU } \\
\text { regulatory constraint) }\end{array}$ & 3.8 ha \\
$\begin{array}{l}\text { Maximum sugarbeet area } \\
\text { from Finland's sugar quota) }\end{array}$ & 0.5 ha \\
$\begin{array}{l}\text { Maximum buffer strip area } \\
\text { Maximum buffer zone area }\end{array}$ & 0.22 ha \\
\hline
\end{tabular}

by the mathematical program from the quadratic model and assume them to have mean zero. As the values of the explanatory variable are non-stochastic, ordinary least squares (OLS) estimation then provides an unbiased estimate of the parameter $\beta$.

\section{Results}

We assessed abatement costs under the 2003 CAP subsidy regime and under the reformed CAP system adopted in 2006. Figures $2 \mathrm{a}$ and $2 \mathrm{~b}$ display the simulated abatement costs and the estimated abatement cost functions together with their $95 \%$ confidence intervals. The estimated abatement cost parameters are $\beta_{2003}=1.86$ for the BASE 2003 system and $\beta_{2006}=1.47$ for the CAP 2006 regime. The corresponding t-values, 27.95 for $\beta_{2003}$ and 37.44 for $\beta_{2006}$, are well above the critical value, and both parameters are significant at the $1 \%$ level. The $95 \%$ confidence interval for $\beta_{2003}$ is 1.73 to 1.99 , and for $\beta_{2006} 1.39$ to 1.55 . In both estimations $\mathrm{R}^{2}$ exhibits a high value (0.96 for BASE 2003 and 0.98 for CAP 2006), indicating a good fit to the model. The unconstrained nitrogen loads were 10 116 tn and 9740 tn per annum for BASE 2003 for CAP 2006, respectively, and the unconstrained phosphorus loads 350 and 356 tn per annum. The average phosphorus load reduction associated with a given nitrogen load reduction was $A_{P}=0.0058 A_{N}$
Cost in EUR (millions)

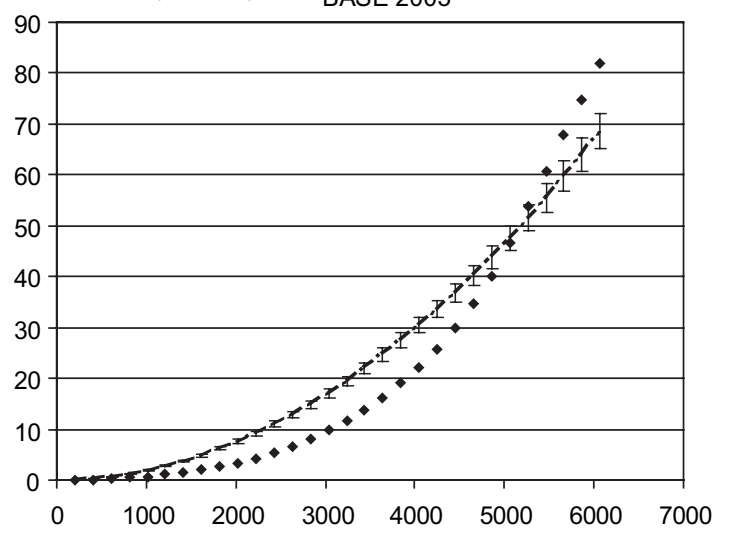

CAP 2006

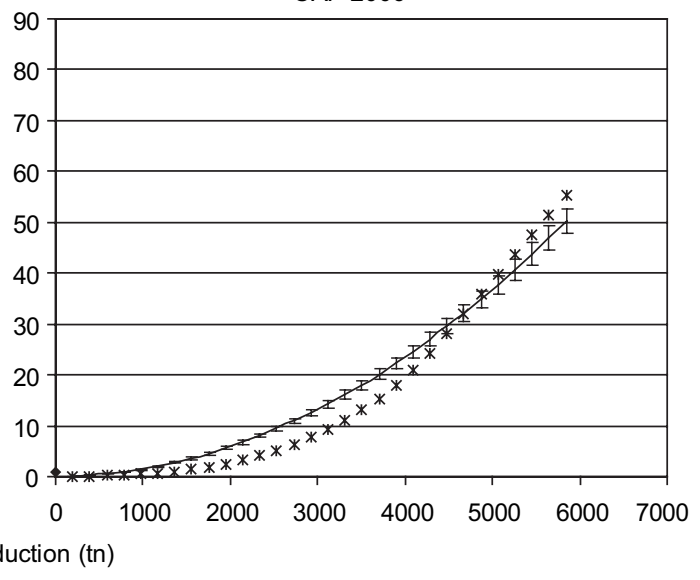

I $95 \%$ confidence interval for predicted cost

Fig. 2. Predicted (OLS) and simulated costs for the research area. 
for BASE 2003, and $\mathrm{A}_{\mathrm{P}}=0.0071 \mathrm{~A}_{\mathrm{N}}$ for CAP 2006.

Given the $50 \%$ uniform load reduction target that the Helsinki Convention has set for Finnish agriculture, we computed the cost of reducing nitrogen loading in the study region by $50 \%$. The resulting total abatement costs are $€ 47.6$ million under BASE 2003, and the average abatement costs $€ 9.4$ per $\mathrm{kg}$ or $€ 99$ per ha. The cost to a typical farm in southern Finland would be $€ 3756$, which equals $49 \%$ of the environmental subsidies received by the typical farm in the region in 2003. The reduction in phosphorus loading associated with the $50 \%$ reduction in nitrogen loading would a mere $2 \%$. Under the CAP 2006 regime the total cost of a $50 \%$ reduction in nitrogen loading would be $€ 34.9$ million ( $€ 7.2$ per $\mathrm{kg}$, $€ 72$ per ha or $€$ 2752 for the typical farm) and the associated reduction in phosphorus loading again only $2 \%$.

Gren et al. 1995 found the abatement cost range for Finnish agriculture to be $€ 6-24$ per kg of nitrogen and $€ 24-662$ per $\mathrm{kg}$ of phosphorus. The abatement costs were estimated based on fertilizer demand, using catch crops, energy forests and green fallow as abatement measures. Finnish data were used to derive the fertilizer demand in Finnish study region while the costs of abatement measures were assumed to be the same as in the Swedish Bothian Bay catchment. The lowest cost abatement measure in their study was the reduction of fertilizer inputs. Our model allows for buffer strips, which reduces the costs compared to those obtained by Gren et al. As several model assumptions differ in the two studies, the results can only be compared roughly. The same caveat applies to comparing our results to those in Brady (2001, 2003). Nevertheless, our results support Hart and Brady (2002), who found that significant reductions in nitrogen losses can be obtained at a relatively small decrease in gross profits.

Figure 3 illustrates the effect of load restrictions on farm profits. ${ }^{7}$ As one would expect, profits decrease when the load restriction is tightened. Here the CAP reform reduces profits relative to the

7 We considered variable profits. Thus fixed costs on capital were not included in the analysis.

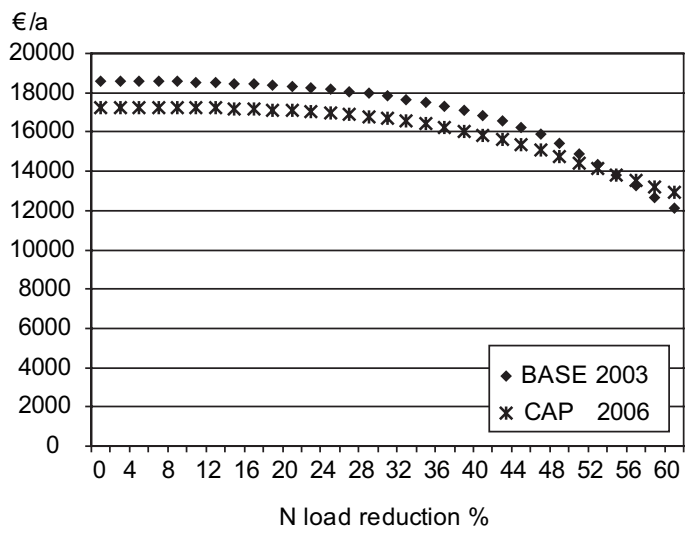

Fig. 3. Profits of the representative farm as a function of nitrogen load constraint.

BASE 2003 level for most load restrictions. ${ }^{8}$ The EU and national subsidies form a significant share of farm profits, which smoothes the effect of tighter load restrictions. Fixed costs and subsidies affect the allocation of land between different crops, but do not affect the choice of fertilizer application rate or the width of buffer strip once the crop choice has been made. Figures $4 \mathrm{a}$ and $4 \mathrm{~b}$ depict the effect of load constraints on crop choice under the two subsidy regimes. As the load constraint is tightened, a larger share of land is allocated to green fallow under both subsidy regimes. The decoupling of subsidies from crop type in CAP 2006 favors turnip rape and silage relative to the BASE 2003 system. As the amount of available land is constant by assumption, a part of barley production is replaced by turnip rape. The area under barley is further decreased and replaced by silage as the load constraint is tightened. By assumption, the region retains its grain production emphasis and animal husbandry remains at its 2003 level, which limits silage production. The area allocated

8 The Finnish government has agreed to compensate farmers for the loss of CAP subsidies following the 2006 reform, but the level of compensation remains undecided (as of 2 Aug 2006). Hence the compensation has not been included here. 
Vol. 15 (2006): 351-374.


Fig. 4. Representative farm's allocation of land between different crop types as a function of nitrogen load constraint.

to the most profitable crop, sugar beet, is constrained by the EU sugar quota. The constraint is binding for both subsidy regimes and for all load restrictions considered.

Brady $(2001,2003)$ obtained a broader selection of crops than the one suggested by our model. He also found more changes in the land cultivation practices. The broader scope of crop choices may be due to the larger number of hectare constraints in Brady's study. Adding modelling constraints is a trade-off between the description of the farmers' adaptation possibilities and a more detailed description of current farming practices. Furthermore, the possibility of establishing buffer strips, not considered in Brady (2003), provides farmers with an alternative way to reduce the nutrient load.

Here, load restrictions decrease yield levels. Figures $5 \mathrm{a}$ and $5 \mathrm{~b}$ depict yields as a percentage of the levels produced by the unconstrained solution. Fertilization levels are presented in Figures $6 \mathrm{a}$ and $6 \mathrm{~b}$. The decline in yields is explained by reduced fertilization. The yield curves level as converting land to green fallow becomes more profitable than further reductions in fertilizer use. Fertilizer use is reduced notably to meet tightening load constraints. For sugar beet and turnip rape fertilization is cut by up to $100 \%$, while fertilization of barley is reduced by up to $60 \%$ and that of silage by up to $30 \% .{ }^{9}$

The use of buffer strips as an abatement measure is illustrated in Figure 7. The maximum buffer area eligible for CAP hectare subsidies was $0.5 \%$ of arable land in the region, whereas the maximum buffer potential estimated to yield environmental benefits was $3 \%$. Under both subsidy regimes, the buffer area exceeds the area eligible for CAP support when nitrogen loads are restricted moderately. The strictest abatement targets are met by increasing the share of green fallow, which results in a decrease in the buffer area. This is logical as green fallow is eligible to CAP subsidies, while buffer zones are not. Buffer zones are established mainly on area in barley.

9 The positive constant terms in the sugar beet and turnip rape yield functions make farming the crops profitable even at zero fertilization. While yield levels are likely to remain positive, the yield response function may be inaccurate at zero fertilization. 
Helin, J. et al. Abatement costs for agricultural nutrient load in SW Finland

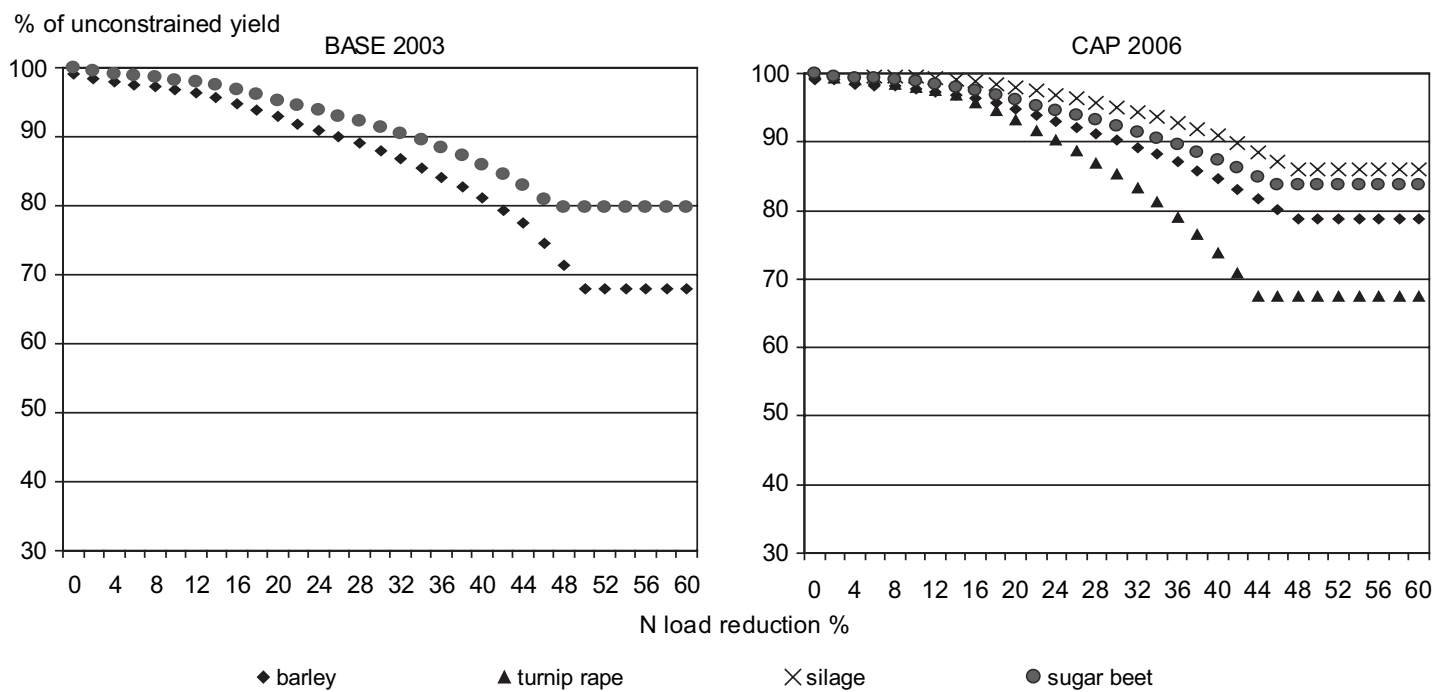

Fig. 5. Effects of nitrogen abatement on total yields: the constrained yield as a percentage of the yield in the unconstrained optimum.


Fig. 6. Fertilization levels as a function of nitrogen load constraint.

As can be seen from Figures 4-7, a combination of different abatement measures is used to achieve least cost abatement. Moderate load restrictions are met by reducing fertilization and introducing buffer strips. Large load reductions are obtained through decreasing fertilization further and through conversion to green fallow. Switching of tillage method did not occur. ${ }^{10}$ The level of LFA

${ }^{10}$ Both the tillage method and crop choice were sensitive to the initial values provided to the optimization algorithm. Variables with an initial level of zero are undesirable 
Vol. 15 (2006): 351-374.

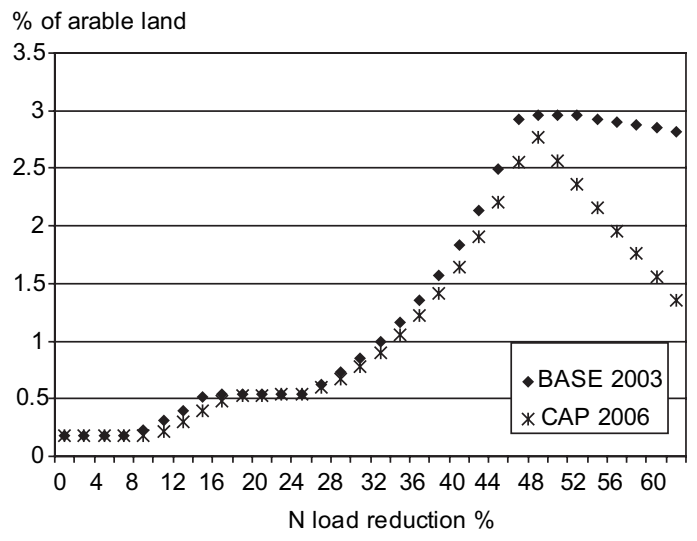

Fig. 7. Buffer area as a function of the nitrogen load.

support and CAP payments to fallow increase in the CAP 2006 system relative to the BASE 2003 regime. As buffer zones exceeding the width of 3 $m$ do not receive CAP support but are eligible for LFA payments, the opportunity cost of buffer zones is smaller in the CAP 2006 system. Fallow is also subsidized more, and abatement through setting land aside as green fallow is not as expensive as in the BASE 2003 scenario. These differences explain the smaller overall abatement costs in the CAP 2006 scenario.

Reductions in nitrogen load lead to only modest reductions in phosphorus loads. Under the CAP 2006 regime, the phosphorus load actually increases at $\bar{L}_{N}=9200 \mathrm{tn}$, which corresponds to a $6 \%$ reduction in the allowed nitrogen load. The increase follows from part of barley production being replaced by silage, which produces markedly higher loss of dissolved reactive phosphorus than the other crops considered here (Table 6). The small

for non-linear optimization, as they appear to have no effect on the profit function (Drud 2004). This effect hampers the switch between the tillage practices, which do not have large dissimilarities in the parameter values. Assigning arbitrary initial values instead of the values obtained from the previous iteration leads to solutions which are local optima but produce lower profits, although tillage method switching occurs frequently.

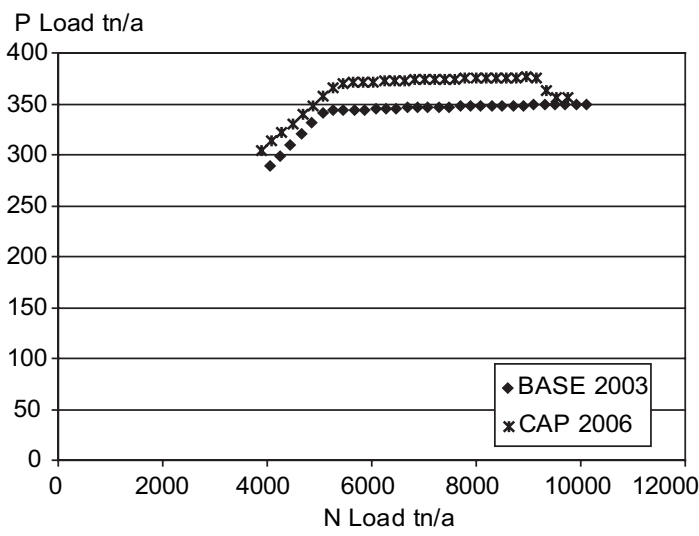

Fig. 8. Phosphorus load for the region as a function of nitrogen load.

changes in the phosphorus load are also explained by the impact of soil phosphorus status on the load. In addition to current farming practices, both dissolved reactive phosphorus and particulate phosphorus loads are affected by the soil phosphorus status (equations 14 and 15) which cannot be decreased by farmers in the short run. Our results indicate a higher average cost of phosphorus abatement than Gren et al. (1995) who, however, did not account for the effect of soil phosphorus status on phosphorus loads.

Above we discussed the costs of nutrient abatement under two alternative agricultural policy regimes. Finnish agriculture is currently facing a downward trend in crop prices and an upward trend in input prices (Niemi and Ahlstedt 2004). To illustrate the effect of these trends in key economic variables on the abatement costs we studied two alternative parameterizations: one where the crop prices were reduced by $10 \%$ and one where nitrogen fertilizer prices increased by $50 \%$. The main results for each policy regime are reported in Table 11. The full set of results is available from the authors upon request. The shares of sugar beet and turnip rape were relatively consistent at different prices, but the shares of other crops, tillage, fertilizer use and buffer strip width varied. Barley was replaced by winter wheat when the prices of all crops were decreased by $10 \%$, and when the nitro- 
gen price was increased and the allowed load reduced by more than $40 \%$. The effects of the parameter changes on the unconstrained nitrogen loads and abatement costs are as one would expect: a decrease in crop prices or an increase in fertilizer prices decrease the unconstrained nitrogen load. A $10 \%$ increase in crop prices had little or no effect on the cost of halving the nitrogen load from the associated unconstrained nitrogen load. A marked increase of $50 \%$ in the nitrogen price resulted in a 15 to $20 \%$ increase in the cost of halving the nitrogen load.

We also tested the sensitivity of the profit optima found by the optimization algorithm to the initial levels of the key variables. The crop choice and the tillage method were sensitive to the initial values of hectares and nitrogen fertilization used in the optimization, while the maximum profit levels were not affected significantly. The sensitivity is due to non-linearities in the production and load functions. The choice of plausible initial values and bounds for variables is a normal part of nonlinear optimization problems. Initial levels for land were allocated based on the current regional distribution of crops (Yearbook of farm statistics 2003). Fertilizer use was initialized at the unconstrained profit maximizing level. For each consequent iteration on the load constraint, the variable values from the previous iteration were used as starting values. This produced relatively smooth yield and profit curves.

\section{Discussion and conclusions}

We studied the costs of agricultural nutrient abatement for crop farming in south-western Finland. Our study area covered approximately $21 \%$ of the Finnish arable lands. Compared to previous studies we considered an extensive selection of crops and farming technologies and described them by nonlinear functional forms estimated from a large set of empirical data. We also modelled the loads of two nutrients simultaneously, where many studies have focused on a single nutrient and neglected the effect of reduction measures on the other. The modelling framework described here can be applied to other regions, and the results can be used in empirical studies and decision support systems tackling with optimal nutrient abatement.

Empirical modelling of agricultural loads and abatement costs is a challenging task. Data requirements are vast. Whereas economic data are relatively easy to obtain and applicable to the entire region, data on crop yield and nutrient loads are specific to crop and the characteristics of each parcel of land, most notably the slope and soil type. Furthermore, weather affects both the farm yields and nutrient loads. For tractability, we abstracted from heterogeneity in land and farmer characteristics, and from uncertainty pertaining to weather conditions. We focused on crop farming, which is predominant in the study region, and con-

Table 11. Main results of the sensitivity analysis.

\begin{tabular}{|c|c|c|c|c|c|c|}
\hline & \multicolumn{3}{|c|}{ BASE 2003} & \multicolumn{3}{|c|}{ CAP 2006} \\
\hline & $\begin{array}{c}2003 \\
\text { commodity } \\
\text { and fertilizer } \\
\text { prices }\end{array}$ & $\begin{array}{c}10 \% \\
\text { decrease in } \\
\text { crop prices }\end{array}$ & $\begin{array}{c}50 \% \\
\text { increase in } \\
\text { nitrogen } \\
\text { price }\end{array}$ & $\begin{array}{c}2003 \\
\text { commodity } \\
\text { and fertilizer } \\
\text { prices }\end{array}$ & $\begin{array}{c}10 \% \\
\text { decrease in } \\
\text { crop prices }\end{array}$ & $\begin{array}{c}50 \% \\
\text { increase in } \\
\text { nitrogen } \\
\text { price }\end{array}$ \\
\hline Estimated coefficient & 1.86 & 1.92 & 2.57 & 1.47 & 1.69 & 2.18 \\
\hline $\mathrm{R}^{2}$ & 0.96 & 0.97 & 0.97 & 0.98 & 0.99 & 0.98 \\
\hline $\begin{array}{l}\text { Unconstrained nitrogen } \\
\text { load (tn) }\end{array}$ & 10116 & 9593 & 8380 & 9740 & 8576 & 7989 \\
\hline $\begin{array}{l}\text { Costs of } 50 \% \text { reduction } \\
\text { in } N \text {-load } € \mathrm{~kg}^{-1}\end{array}$ & 9.4 & 9.2 & 10.8 & 7.2 & 7.2 & 8.7 \\
\hline
\end{tabular}


Vol. 15 (2006): 351-374.

sidered farming decisions where the time horizon is one year. The long run effect of nitrogen load restrictions or other water protection measures on phosphorus loss is likely to be larger than the one predicted by our short run model. Assessing the long run impacts would require a dynamic model tracking changes in soil phosphorus status, which merits full attention in a separate future study. We also assumed that machinery can be rented and hence that farmers do not face capacity constraints, and that labor is not constrained. These assumptions are reasonable in that contractor services are widely available in Finland and crop production is not particularly labor intensive. By the Le Chatelier principle (Samuelson 1983), the abatement costs would be at least as large as those suggested by our analysis if machinery or labor constraints were added. The effect of relaxing the assumption of fixed area of agricultural land would be the opposite: the abatement costs would be at most as large as those obtained here.

The land allocation produced by the model under the BASE 2003 regime differs from the observed land allocation in 2003 even when nutrient loads are not restricted. The discrepancy follows from the modelling choice of no heterogeneity in soil quality and farmer skills, whereby barley becomes the most profitable cereal for the representative farm and replaces all other cereals. While accounting for heterogeneity would be an important extension, one can argue that the land allocation produced by our model is a reasonable approximation. As in the 2003 observed land allocation, most land is in cereal production, and barley is the predominant crop. Abstracting from heterogeneity of soil types and other environmental factors may, however, overestimate the abatement costs (for an empirical example see Johansson 2004). Large scale animal farms produce a challenge for agricultural nutrient abatement, and the abatement costs may also be somewhat over or underestimated due to leaving manure management and animal farms outside the analysis. Nevertheless, our re- sults on crop farming are of a similar magnitude with previous Danish and Dutch studies on abatement costs in pig farming (Berntsen et al. 2003, Polman and Thijssen 2002). Catch crops could also provide a low cost abatement alternative (Gren et al. 1995), but they have not been common in Finland and no empirical data are available on their effect on nutrient loading in the study region. Hence, catch crops were not considered in this study.

The differences in the results pertaining to the BASE 2003 and CAP 2006 regimes support the findings by Hofreither 2003 and Serra et al. 2004 that decoupling agricultural subsidies from production reduces the environmental impacts of agriculture. Wier et al. (2002) on the contrary found that the EU Agenda 2000 reform, which involved reductions in price support and compensations in the form of hectare support, had almost no effects on the environment. In our analysis the latest CAP reform, adopted in Finland in 2006, led to slight decreases in farmers' variable profits, the unconstrained nitrogen load, and abatement costs. The results are also in line with Lehtonen et al. (2006), according to whom significant reductions in nutrient loading would require radical policy changes. All in all, our results support changes in the design and implementation of further agri-environmental nutrient policies in Finland. Efficiency and enforcement issues should be taken seriously, as our analysis suggests that load reductions could be obtained without excessive costs or marked income transfers from taxpayers to farmers.

Acknowledgements. The authors would like thank Tapio Salo and Sirkka Tattari for providing the data on the effect of crop choice and tillage method on nitrogen and phosphorus loading. The authors are also indebted to Petri Ekholm, Anni Huhtala, Jussi Lankoski, Markku Puustinen, Antti Räike and Risto Uusitalo for insightful comments and useful discussions over the course of this study. The authors are solely responsible for all remaining errors. 


\section{AGRICULTURAL AND FOOD SCIENCE}

Appendix 1. Solution to the constrained optimization problem.

The optimization problem defined in equations (1) to (6) is solved using nonlinear programming. The Lagrange function is specified as

$$
\begin{aligned}
\mathrm{L}= & \sum_{j=1}^{J} \sum_{k=1}^{K}\left\{\left[p_{j} f_{j, k}\left(N_{j, k}\right)-p_{N} N_{j, k}-c_{j, k}+s_{j, k}\right]\left(1-B_{j, k}\right)-c_{B, j, k} B_{j, k}\right\} X_{j, k} \\
& +\sum_{i=1}^{I} \mu_{i}\left(\bar{R}_{i}-\sum_{j=1}^{J} \sum_{k=1}^{K} r_{i, j, k} X_{j, k}\right)+\lambda\left(\bar{L}_{N}-\sum_{j=1}^{J} \sum_{k=1}^{K} e_{j, k}\left(N_{j, k}, B_{j, k}\right) X_{j, k}\right) \\
& +\eta\left(\bar{B}-\sum_{j=1}^{J} \sum_{k=1}^{K} B_{j, k}\right) .
\end{aligned}
$$

The Kuhn-Tucker conditions for the problem in (A1) are

$$
\begin{aligned}
\frac{\partial \mathrm{L}}{\partial X_{j, k}}= & {\left[p_{j} f_{j, k}\left(N_{j, k}\right)-p_{N} N_{j, k}-c_{j, k}+s_{j, k}\right]\left(1-B_{j, k}\right)-c_{B, j, k} B_{j, k} } \\
& -\sum_{i=1}^{I} \mu r_{i, j, k}-\lambda e_{j, k}\left(N_{j, k}, B_{j, k}\right) \leq 0 \quad \forall j, k \quad\left(=0 \text { if } X_{j, k}>0\right)
\end{aligned}
$$

$$
\begin{array}{r}
\frac{\partial \mathrm{L}}{\partial N_{j, k}}=\left[p_{j} \frac{\partial f_{j, k}\left(N_{j, k}\right)}{\partial N_{j, k}}-p_{N}\right]\left(1-B_{j, k}\right) X_{j, k}-\lambda \frac{\partial e_{j, k}\left(N_{j, k}, B_{j, k}\right)}{\partial N_{j, k}} X_{j, k} \leq 0 \quad \forall j, k \\
\left(=0 \text { if } N_{j, k}>0\right)
\end{array}
$$

$$
\begin{aligned}
\frac{\partial \mathrm{L}}{\partial B_{j, k}}= & \left\{-\left[p_{j} f_{j, k}\left(N_{j, k}\right)-p_{N} N_{j, k}-c_{j, k}+s_{j, k}\right]-c_{B, j, k}\right\} X_{j, k} \\
& -\lambda \frac{\partial e_{j, k}\left(N_{j, k}, B_{j, k}\right)}{\partial B_{j, k}} X_{j, k}-\eta \leq 0 \quad \forall j, k \quad\left(=0 \text { if } B_{j, k}>0\right)
\end{aligned}
$$

$$
\begin{aligned}
& \frac{\partial \mathrm{L}}{\partial \mu_{i}}=\bar{R}_{i}-\sum_{j=1}^{J} \sum_{k=1}^{K} r_{i, j, k} X_{j, k} \geq 0 \quad \forall i \quad\left(=0 \text { if } \mu_{i}>0\right) \\
& \frac{\partial \mathrm{L}}{\partial \lambda}=\bar{L}_{N}-\sum_{j=1}^{J} \sum_{k=1}^{K} e_{j, k}\left(N_{j, k}, B_{j, k}\right) X_{j, k} \geq 0 \quad(=0 \text { if } \lambda>0) \\
& \frac{\partial \mathrm{L}}{\partial \eta}=\bar{B}-\sum_{j=1}^{J} \sum_{k=1}^{K} B_{j, k} \geq 0 \quad(=0 \text { if } \eta>0)
\end{aligned}
$$

In addition, $X_{j, k}$ and $N_{j, k}$ have to satisfy the non-negativity constraints in (3). The solution to the problem in (A1) consists of the values of $X_{j, k}, N_{j, k}$, and $B_{j, k}$ and the associated Lagrange multipliers that satisfy the Kuhn-Tucker conditions in (A2) to (A7). The Lagrange multipliers $\mu_{i}$ express the shadow price of the resource constraints $R_{i}$. The multiplier $\lambda$ represents the shadow cost of the restriction on nitrogen discharges: the value of $\lambda$ shows how much farm profits will fall if the load restriction is tightened by an additional kilogram. That is, the marginal cost of reducing agricultural nitrogen discharges is embedded in $\lambda$. The multiplier $\eta$ gives the shadow value of buffer strips. 


\section{References}

ÆErtebjerg G, Carstensen, J., Dahl, K., Hansen, J., Rygg, B., Sørensen, K., Severinsen, G., Nygaard, K., Schrimpf, W., Schiller, C., Druon, J.N., \& Casartelli, S., 2001. Eutrophication in Europe's coastal waters. European Environmental Agency. Topic report no. 7/2001. Cited 16.8.2006. Updated 18.10.2001. Available on the Internet: http://reports.eea.europa.eu/topic_report_2001_7/ en/Topic_Report 7_2001.pdf

Antle, J.M. \& Just, R.E. $\overline{1991 . ~ E f f e c t s ~ o f ~ c o m m o d i t y ~ p r o g r a m ~}$ structure on resource use and the environment. In: Bockstael, N. \& Just, R.E. (eds.). Commodity and resource policies in agricultural systems. New York: Springer Verlag. p. 97-128.

Bäckman, S., Vermeulen, S. \& Taavitsainen, V. 1997. Longterm fertilizer field trials: comparison of three mathematical response models. Agricultural and Food Science in Finland 6: 151-160.

Baltic Sea GIS 1993. Arc shape files. Norway, UNEP:Grid/ Arendal. Cited 16 Aug 2006. Updated 1 Aug 2006. Available on the Internet: http://www.grida.no/baltic/

Baumol, W. \& Oates, W. 1988. The theory of environmental policy. Cambridge, UK: Cambridge University Press. $297 \mathrm{p}$.

Berntsen, J., Petersen, B.M., Jacobsen, B.H., Olesen, J.E. \& Hutchings N.J. 2003. Evaluating nitrogen taxation scenarios using the dynamic whole farm simulation model FASSET. Agricultural Systems 76: 817-839.

Bock, B. \& Sikora, F. 1990. Modified quadratic/plateau model for describing plant responses to fertilizer. Soil Science Society of America Journal 54: 1784-1789.

Brady, M. 2001. Baltic Sea nitrogen agricultural abatement and ecosystem adaptation models. Uppsala: Swedish University of Agricultural Sciences. $15 \mathrm{p}$.

Brady, M. 2003. Managing agriculture and water quality four essays on the control of large-scale nitrogen pollution. Uppsala: Swedish University of Agricultural Sciences. Cited 16.8.2006. Updated 4.4.2003. Available on the Internet: http://diss-epsilon.slu.se/archive/00000217/ 01/ejfulltext.pdf

Brooke, A., Kendrick, D., Meeraus, A., Raman, R. \& Rosenthal. R. 1998. GAMS user's guide. Washington:GAMS Development Corporation. $169 \mathrm{p}$.

Cerrato, M. \& Blackmer, A. 1990. Comparison of models for describing corn yield response to nitrogen fertilizer. Agronomy Journal 82: 138-143.

Dillaha, T. \& Inamdar, S. 1997. Buffer zones as sediment traps or source. In: Haycock, N. et al. (eds.). Buffer zones: their processes and potential in water protection. Harpenden: Quest Environmental. p. 33-42.

Drud, A. 2004. Conopt user manual. Denmark: Arki Consulting and Development. $44 \mathrm{p}$.

Ekholm, P. \& Krogerus, K. 2003. Determining algal-available phosphorus of differing origin: routine phosphorus analyses vs. algal assays. Hydrobiologia 492: 29-42.

Ekholm, P., Virtainen, J. \& Mitikka, S. 2004. Maatalouden ravinnekuormitus ja sen vesistövaikutukset - arviointi seuranta-aineistojen perusteella, Järvien vedenlaatu.
In:Turtola, E. \& Lemola, R. (eds.). Maatalouden ympäristötuen seuranta MYTVAS 2. Agrifood Research Reports 59. Jokioinen, Finland: MTT Agrifood Research Finland. p. 84-176.

Ekman, S. 2000. Tillage system selection: a mathematical programming model incorporating weather variability. Journal of Agricultural Engineering Research 77: 267276.

Enroth, A. 2004. Mallilaskelmia maataloudesta 2004. ProAgria Maaseutukeskusten Liiton julkaisuja nro 1008. 45 p.

European Commission 2005. Agriculture and rural development - CAP reform. Cited 16 Aug 2006. Updated 26 Jun 2003. http://europa.eu.int/comm/agriculture/capreform/index en.htm

Finnish Field Drainage Center 2002. Salaojituksen tavoiteohjelma 2020. Updated 1 Jan 2003. Cited 16 Aug 2006. Available on the Internet: http://www.salaojakeskus.fi/ pdf/tavoiteohjelma.pdf (in Finnish).

Frank, M., Beattie, B. \& Embleton, M. 1990. A comparison of alternative crop response models. American Journal of Agricultural Economics 72: 597-603.

Granlund, K., Raike, A., Ekholm P., Rankinen, K. \& Rekolainen, S. 2005. Assessment of water protection targets for agricultural nutrient loading in Finland. Journal of Hydrology 304: 251-260.

Gren, I.M., Söderqvist, T. \& Wulff, F. 1997. Nutrient reductions to the Baltic Sea: Ecology, costs and benefits. Journal of Environmental Management 51: 123-143.

Gren, I.-M., Elofsson, K. \& Jannke, P. 1995. Costs of nutrient reductions to the Baltic Sea. Environmental and Resource Economics 10: 341-362.

Hart, R. \& Brady, M. 2002. Nitrogen in the Baltic Sea - policy implications of stock effects. Journal of Environmental Management 66: 91-103.

Hofreihter, M.F., Schmidt, E. \& Sinabell F. 2004. Phasing out environmentally harmful subsidies: Effects of the CAP 2003 reform. American Agricultural Economics Association Annual Meeting, Denver, Colorado, 1-4 July 2004. 20 p.

HELCOM 2003. The review of more specific targets to reach the goal set up in the 1988/1998 Ministerial Declarations regarding nutrients. Helsinki Commission Baltic Marine Environment Protection Commission. $15 \mathrm{p}$.

HELCOM 2005. Nutrient pollution to the Baltic Sea in 2000. Baltic Sea Environment Proceedings 100.16 p.

Johansson, R.C., Gowda, P.H., Mulla, D. \& Dalzell, B. 2004. Metamodelling phosphorus best management practices for policy use: a frontier approach. Agricultural Economics 30: 63-74.

Kosenius, A.-K. 2004. Estimating the benefit from algal bloom reduction - an application of contingent valuation method. Master's thesis, Department of economics and management, Environmental economics, University of Helsinki. 65 p.

Lankoski, J., Ollikainen, M. \& Uusitalo, P. 2006. No-till technology: benefits to farmers and the environment? Theoretical analysis and application to Finnish agriculture. 
European Review of Agricultural Economics 33: 193221.

Larsson, U., Elmgren, R. \& Wulff, F. 1985. Eutrophication and the Baltic Sea. Ambio 14: 9-14.

Lehtonen, H. 2001. Principles, structure and application of dynamic regional sector model of Finnish agriculture. Helsinki: Agrifood Research Finland. 264 p.

Lehtonen, H., Bärlund, I., Tattari, S. \& Hilden M. 2006. Combining dynamic economic analysis and environmental impact modelling: Addressing uncertainty and complexity of agricultural development. Environmental Modelling \& Software. 22: 710-718.

Lilja, H., Uusitalo, R., Yli-Halla, M., Nevalainen, R., Väänänen, T. \& Tamminen. P. 2006. Finnish soil database. MTT:n selvityksiä 114. Jokioinen, Finland: Agrifood Research Finland. 54 p.

Magette, W. 1998. Factors affecting losses of nutrients from agricultural systems and delivery to water resources. In: Carton, O. (ed.), Draft guidelines for nutrient use intensive agricultural enterprises. Teagasc, Johnstown Castle, Wexford, Ireland. p. 6-31.

Mattsson, C. \& Carlsson, N. 1983. Plant nutrients in agriculture. Part 2. Studies of the profitability of nitrogen fertilization at farm level. Report 214. Upsala: Swedish University of Agricultural Sciences. $74 \mathrm{p}$.

The Ministry of Agriculture and Forestry 2006a. Hakuopas 2006. Helsinki: The Ministry of Agriculture and Forestry. $131 \mathrm{p}$.

The Ministry of Agriculture and Forestry 2006b. Etelä-Suomen kansallisen tuen, pohjoisen tuen, ympäristötuen, kansallisen lisäosan ja perunantuotannon kansallisen tuen tukitasot vuonna 2006. Helsinki: The Ministry of Agriculture and Forestry. $3 \mathrm{p}$.

The Ministry of Agriculture and Forestry 2004. Horisontaalisen maaseudun kehittämisohjelman väliarviointi: Manner-Suomi. Maa- ja metsätalousministeriön julkaisuja Helsinki: The Ministry of Agriculture and Forestry. $272 \mathrm{p}$.

The Ministry of Environment 1998. Water Protection Targets to 2005. The Finnish Environment 226. Helsinki: The Ministry of Environment. $82 \mathrm{p}$.

Myyrä, S., Ketola, E., Yli-halla, M. \& Pietola, K. 2005. Land improvements under land tenure insecurity: the case of $\mathrm{pH}$ and phosphate in Finland. Land Economics 81: 557-569.

Niemi, J. \& Ahlstedt, J. (eds.). 2003. Finnish agriculture and rural industries 2003. Helsinki: MTT Agrifood Research Finland. $94 \mathrm{p}$.

Niemi, J. \& Ahlstedt, J. (eds.). 2005. Finnish agriculture and rural industries 2005. Helsinki: MTT Agrifood Research Finland. $94 \mathrm{p}$.

Patty, L., Réal, B. \& Gril, J. 1997. The use of grassed buffer strips to remove pesticides, nitrate and soluble phosphorus compounds from runoff water. Pesticide Science 49: 243-251.

Pentti, S. 2003. Konetyön kustannukset ja tilastolliset urakointihinnat. Työtehoseuran maataloustiedote 7/2003. $12 \mathrm{p}$.

Penttilä, S. 2003. Suojavyöhykkeiden ja maisemanhoidon yleissuunnitelma Uudenmaan ympäristökeskuksen alueella. Uudenmaan ympäristökeskus. Moniste 133. $40 \mathrm{p}$.
Petrolia, D.R. \& Prasanna H.G. 2006. Missing the boat: Midwest farm drainage and Gulf of Mexico Hypoxia. Review of Agricultural Economics 28: 240-253.

Polman, N. \& Thijssen, G. 2002. Combining results of different models: the case of a levy on the Dutch nitrogen surplus. Agricultural Economics 27:41-49.

Puustinen, M., Koskiaho, J. \& Peltonen, K. 2005. Influence of cultivation methods on suspended solids and phosphorus concentrations in surface runoff on clayey sloped fields in boreal climate. Agriculture, Ecosystems \& Environment 105: 565-579.

Puustinen, M., Merilä, E., Palko, J. \& Seuna, P. 1994. Kuivatustila, viljelykäytäntö ja vesistökuormitukseen vaikuttavat ominaisuudet Suomen pelloilla. Vesi- ja ympäristöhallituksen julkaisuja 198. 130 p.

Räike, A., Granlund, K. \& Ekholm, P. 2004. Maatalouden ravinnekuormitus ja sen vesistövaikutukset - arviointi seuranta-aineistojen perusteella, ravinnekuormitus. In: Turtola, E. \& Lemola, R. (eds.). Maatalouden ympäristötuen seuranta MYTVAS 2. Agrifood Research Reports 59. Jokioinen, Finland: MTT Agrifood Research Finland. p. 97-176.

Randall, G.W., Huggins, D.R., Russelle, M.P., Fuchs, D.J., Nelson, W.W. \& Anderson, J.L. 1997. Nitrate losses through subsurface tile drainage in Conservation reserve program, alalfa, and row crop systems. Journal of Environmental Quality 26: 1240-1247.

Randall, G.W. \& Mulla, D.J. 2001. Nitrate nitrogen in surface waters as influenced by climatic conditions and agricultural practices. Journal Environmental Quality 30: 337344.

Saarela, I., Järvi, A., Hakkola, H. \& Rinne, K. 1995. Fosforilannoituksen porraskokeet 1977-1994. Vuosittain annetun fosforimäärän vaikutus maan viljavuuteen ja peltokasvien satoon monivuotisissa kenttäkokeissa. (Summary: Phosphorus fertilizer trials, 1977-1994: effects of the rate of annual phosphorus application on soil fertility and yields of fields crops in long-term field experiments). Agricultural Research Centre of Finland, Tiedote 16/95. 94 p.

Saarela, I., Järvi, A., Hakkola, H. \& Rinne, K. 2003. Phosphorus status of diverse soils in Finland as influenced by long-term $P$ fertilisation. I. Native and previously applied $\mathrm{P}$ at 24 experimental sites. Agricultural and Food Science in Finland 12: 117-132.

Samuelson, P. 1983. Foundations of economic analysis. Enlarged Edition. USA: Harvard University Press. $353 \mathrm{p}$.

Sandström, M., Scharin, H. \& Söderqvist, T. 2000. Seaside recreation in the Stockholm archipelago: travel patterns and costs. Beijer Discussion Paper, Series No. 129. $20 \mathrm{p}$.

Schou, J.S., Skop, E. \& Jensen, J.D. 2000. Integrated agrienvironmental modelling: A cost-effectiveness analysis of two nitrogen tax instruments in the Vejle Fjord watershed, Denmark. Journal of Environmental Management 58: 199-212.

Serra, T., Zilberman, D., Goodwin, B.K. \& Hyvönen, K. 2004. Replacement of price support measures by direct payments in agricultural policies. Does this benefit the environment? The effects of the post 1992 CAP on pest control in the EU. American Agricultural Economics As- 
Vol. 15 (2006): 351-374.

sociation Annual Meeting, Denver, Colorado, 1-4 July 2004. 28 p.

Shortle, J.S. \& Abler, D.G. 2001. Environmental policies for agricultural pollution control. Wallingford: CABI Publishing. $240 \mathrm{p}$.

Simmelsgaard, S.E. \& Djurhuus, J. 1998. An empirical model for estimating nitrate leaching as affected by crop type and the long-term fertilizer rate. Soil Use and Management 14: 37-43.

Simmelsgaard, S.E. 1991. Estimation of nitrogen leakage functions - nitrogen leakage as a function of nitrogen applications for different crops on sandy and clay soils. In: Rude, S. (ed.). Kavelstofgödning i landbruget - behov og udvasking nu og i fremtiden. Summary: Nitrogen fertilizers in Danish agriculture - present and future application and leaching. Copenhagen. Institute of Agricultural Economics Report 62. p. 135-150.

Söderqvist, T. \& Scahrin, H. 2000. The regional willingness to pay for a reduced eutrophication in the Stockholm archipelago. Beijer Discussion Paper, Series No. 128. $23 \mathrm{p}$.

Soileau, J.M., Touchton, J.T., Hajek, B.F. \& Baglio, J.V. 1994. Sediment, nitrogen \& phosphorus runoff with conventional- and conservation tillage cotton in a small watershed. Journal of Soil \& Water Conservation 48: 449457.

Stonehouse, D.P. 1997. Socio-economics of alternative tillage systems. Soil \& Tillage Research 43: 109-130.

Tattari, S., Bärlund, I., Rekolainen, S., Posch, M., Siimes, K., Tuhkanen, H.R. \& Yli-Halla, M. 2001. Modeling sediment yield and phosphorus transport in Finnish clayey soils. Transactions of the American Society of Agricultural Engineers 44: 297-307.

TIKE 2004. Agricultural statistical bulletin 1/2004. Helsinki: The Information Centre of the Ministry of Agriculture and Forestry. $19 \mathrm{p}$.

Turpin, N., Bontems, P., Rotillon, G., Barlund, I., Kaljonen, M., Tattari, S., Feichtinger, F., Strauss, P., Haverkamp, R. \& Garnier, M. 2005. AgriBMPWater: systems approach to environmentally acceptable farming. Environmental Modelling \& Software 20: 187-196.

Turtola, E. \& Lemola, R. (eds.). 2004. Maatalouden ympäristötuen seuranta MYTVAS. Agrifood Research Reports 59. Jokioinen, Finland: Agrifood Research Finland. $169 \mathrm{p}$.

Turtola, E. \& Paajanen, A. 1995. Influence of improved subsurface drainage on phosphorus losses and nitrogen leaching from a heavy clay soil. Agricultural Water Management 28: 295-310.

Uusi-Kämppä, J. 2005. Phosphorus purification in buffer zones in cold climates. In: Mander, U. et al. (eds.). Riparian buffer zones in agricultural watersheds. Ecological Engineering 24, 5: 491-502.

Uusi-Kämppä, J., Braskerud, B., Jansson, H., Syversen, N. \& Uusitalo, R. 2000. Buffer zones and constructed wetlands as filters for agricultural phosphorus. Journal of Environmental Quality 29: 151-158.

Uusi-Kämppä, J. \& Kilpinen, M. 2000. Suojakaistat ravinnekuormituksen vähentäjänä. Maatalouden tutkimuskeskuksen julkaisuja Sarja A 83. Jokioinen, Finland: Agricultural Research Centre of Finland. 49 p. + 2 app.

Uusi-Kämppä, J. \& Yläranta, T. 1992. Reduction of sediment, phosphorus and nitrogen transport on vegetated buffer strips. Agricultural Science in Finland 1: 569575.

Uusi-Kämppä, J. \& Yläranta. T. 1996. Effect of buffer strip on controlling erosion and nutrient losses in Southern Finland. In: Mulamoottil, G. et al. (eds.). Wetlands: environmental gradients, boundaries and buffers. Boca Raton: CRC Press/Lewis Publishers. p. 221-235.

Uusitalo, P. \& Eriksson, C. 2004. Viljanviljelyn perusmuokkausmenetelmien taloudellisuusvertailu. Abstract: The effect of tillage method on crop yield. Agrifood Research Reports 60. Jokioinen, Finland: MTT Agrifood Research Finland. 48 p.

Uusitalo, R. \& Jansson, H. 2002. Dissolved reactive phosphorus in runoff assessed by soil extraction with an acetate buffer. Agricultural and Food Science in Finland 11: 343-353.

Uusitalo, R., Turtola, E., Puustinen, M., Paasonen-Kivekäs, M. \& Uusi Kämppä, J. 2003. Contribution of particulate phosphorus to runoff phosphorus bioavailability. Journal of Environmental Quality 32: 2007-2016.

Wier, M., Andersen, J.M., Jensen, J.D. \& Jensen, T.C. 2002. The EU's Agenda 2000 reform for the agricultural sector: environmental and economic effects in Denmark. Ecological Economics 41: 345-359.

Yearbook of farm statistics 2004. Official statistics of Finland. Helsinki: Information Centre of the Ministry of Agriculture and Forestry. $268 \mathrm{p}$.

Yiridoe, E. \& Weersink, A. 1998, Marginal abatement costs of reducing groundwater-N pollution with intensive and extensive farm management choices. Agricultural and Resource Economics Review 27: 169-185. 
Helin, J. et al. Abatement costs for agricultural nutrient load in SW Finland

\title{
SELOSTUS
}

\section{Malli selvittää typpikuormituksen vähentämisen kustannukset}

\author{
Janne Helin, Marita Laukkanen ja Kauko Koikkalainen
}

MTT Taloustutkimus

Tehokkaan maatalouden ympäristöpolitiikan suunnitteluun vaaditaan tietoa ravinnekuormituksen vähentämisen kustannuksista. Tässä tutkimuksessa kehitettiin empiirinen malli, jonka avulla kyetään arvioimaan maatalousmaan ravinnekuormituksen vähentämisestä aiheutuvia kustannuksia. Mallilla voidaan selvittää typpikuormituksen vähentämisen ja siitä johtuvan fosforikuormituksen pienenemisen kustannukset Etelä-Suomessa.
Tutkimuksessa analysoidaan Euroopan Unionin yhteisen maatalouspolitiikan vaikutuksia ravinnekuormituksen vähentämisen kustannuksiin sekä uuden että edeltävän tukijärjestelmän valossa. Tulokset osoittavat, että tehokkaalla politiikalla typpikuormituksen vähentäminen puoleen tulisi maksamaan 48-35 miljoonaa euroa, eli 3756-2752 euroa tilaa kohden. 